\title{
Assessment of clinical and pathological complete response after neoadjuvant chemoradiotherapy in rectal adenocarcinoma and its therapeutic implications
}

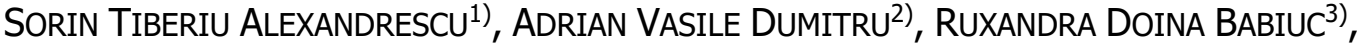 \\ RADU VIRGIL COSTEA ${ }^{1)}$
}

\author{
1) Department of General Surgery, Carol Davila University of Medicine and Pharmacy, Bucharest, Romania \\ 2) Department of Morphological Sciences, Carol Davila University of Medicine and Pharmacy, Bucharest, Romania \\ 3) Department of Internal Medicine I - Gastroenterology, Carol Davila University of Medicine and Pharmacy, Bucharest, Romania
}

\begin{abstract}
Because almost one fourth of patients with rectal adenocarcinoma (RC) achieve pathological complete response (pCR) after neoadjuvant chemoradiation therapy (CRT), having significantly higher survival rates than those without $p C R$, the assessment of $p C R$ represents a highly important challenge nowadays. Moreover, recent studies revealed that organ-sparing approaches could represent a reasonable alternative to radical surgery (RS) in patients with $\mathrm{pCR}$, achieving similar long-term outcomes with lower morbidity rates and improved quality of life. Unfortunately, the decision of a rectum-sparing approach should be based only on clinical, endoscopic (with or without biopsy) and radiological methods, that must accurately predict the $\mathrm{pCR}$ after neoadjuvant CRT, in the absence of the pathological examination of the RS specimen. Thus, a surrogate parameter called clinical complete response (cCR) emerged, to assess the results of neoadjuvant CRT. The evolving accuracy of recent endoscopic and imaging methods in assessment of CCR and their predictive value for estimation of $p C R$ achievement are presented. The usefulness of combining the results of these evaluation methods (resulting in the development of few nomograms) for a more accurate estimation of pCR, as well as the predictive factors for pCR achievement are also debated. Moreover, the changing landscape of therapeutic approaches based on cCR assessment is discussed, emphasizing the advantages and pitfalls of rectum-sparing approaches, compared to RS. Because there are no reliable methods to estimate with $100 \%$ accuracy the PCR, the only way to decrease as much as possible the risk of misleading treatment choices is the multidisciplinary team-based decision.
\end{abstract}

Keywords: rectal cancer, complete response, neoadjuvant chemoradiation therapy, local excision.

\section{口 Introduction}

Since the late ' 70 s, rectal resection with total mesorectal excision (TME) became the standard surgical approach to rectal carcinomas (RCs) [1]. Even this surgical approach decreased the five-year local recurrence rates (LRRs) from $12-20 \%$ [2] to $8.5 \%$ in the series operated by Heald et al. between 1978 and 1987 [3], further decrease in the fiveyear LRR (3\%) was achieved by the same authors between 1988 and 1997, probably due to the extent use of preoperative radiotherapy (RT) [3]. Moreover, in 1999, Vauthey et al. revealed that the addition of chemotherapy to preoperative RT significantly improved overall survival (OS) in patients operated for locally advanced rectal cancer (LARC) [4], although LRR was not influenced by the use of neoadjuvant chemotherapy. Moreover, a recent study revealed that the addition of chemotherapy to neoadjuvant RT was an independent predictor for better progression free survival in patients with cT1-2N0M0 RC [5]. Correspondingly, preoperative chemoradiation therapy (CRT) was able to induce down-staging of RC in 50-60\% of patients [6-10] with LARC, leading to a significantly higher rate of sphincter-preserving operations [4].

In a series of 231 patients with cT1-2N0M0 distal RC treated by definitive RT or CRT, 135 (58.4\%) patients experienced macroscopical disappearance of rectal tumor, so-called clinical complete response (cCR) $(76.1 \%$ in cT1N0 patients and $51.2 \%$ in cT2N0 patients) [5]. Furthermore, neoadjuvant CRT determined a cCR in up to $26.8 \%$ of cT2-4N0-2M0 patients [8]. Moreover, among patients with incomplete clinical response, an additional pathological complete response (pCR) was observed in $8.3-16.6 \%$ of patients who underwent radical surgery (RS) with TME after neoadjuvant CRT $[8,11]$. The OS rates achieved by surgical resection in patients with pCR were significantly higher than those observed in patients without pCR [6, 12]. These observations raised the question whether RS could be avoided in good responders (cCR/pCR) to neoadjuvant CRT, and which are the most appropriate selection criteria for treatment allocation. Thus, the accuracy of different diagnostic modalities to assess pCR is crucial to identify those patients who are most likely benefiting from organsparing approaches. Prognostic factors associated with pCR, as well as the influence of various types of neoadjuvant therapy on $\mathrm{pCR}$ rates are presented. Furthermore, alternative strategies to RS are discussed, reporting also their results and future modalities to improve both the short-term and long-term outcomes.

This is an open-access article distributed under the terms of a Creative Commons Attribution-NonCommercial-ShareAlike 4.0 International Public License, which permits unrestricted use, adaptation, distribution and reproduction in any medium, non-commercially, provided the new creations are licensed under identical terms as the original work and the original work is properly cited. 


\section{$\neg$ Definition and assessment of complete response}

pCR represents the absence of malignant cells on the specimen of rectal resection in patients who were previously treated with neoadjuvant CRT. In most studies, this endpoint is reported as ypT0N0, according to the Union for International Cancer Control (UICC) or American Joint Committee on Cancer (AJCC). The same outcome (pCR) is reported in few studies [13] as equivalent with TRG4, according to the tumor regression grade (TRG) system

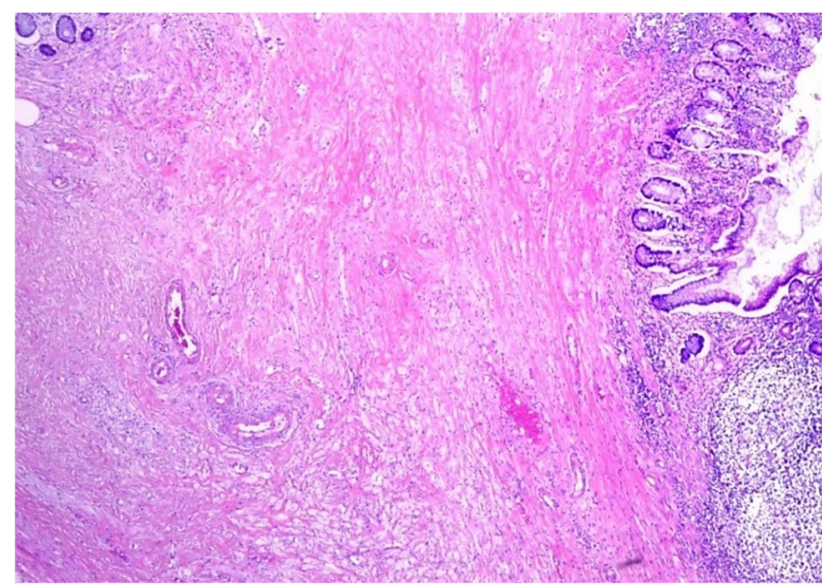

Figure 1 - Complete tumor regression (TRG0/pCR). The absence of viable tumor cells is the highlight of the complete response after neoadjuvant therapy. The entire tumor bed is fibrotic and has multiple foamy macrophages. Observe the architectural distortion of the mucosa as well as its ulceration as a side effect of neoadjuvant treatment. $\mathrm{HE}$ staining, ×40. HE: Hematoxylin-Eosin; pCR: Pathological complete response; TRG: Tumor regression grade.

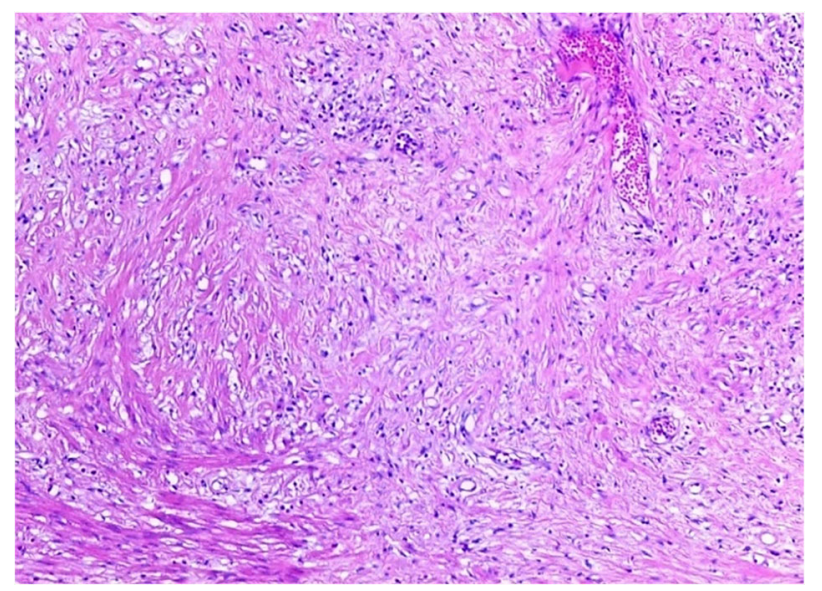

Figure 3 - Microscopic features of the tumor bed in a patient with complete response after neoadjuvant treatment. The whole area is fibrotic with numerous fibroblasts, macrophages, lymphocytes, and blood vessels with thickened or distorted walls. HE staining, $\times 100$.

Table 1 - Criteria for assessment of cCR

\begin{tabular}{|c|c|c|c|c|c|c|c|c|}
\hline Study & DRE & Endoscopy & Biopsy & CT scan & MRI & ERUS & PET/CT & CEA \\
\hline $\begin{array}{c}\text { Habr-Gama } \\
\text { et al. (2004) } \\
{[8]}\end{array}$ & $\begin{array}{l}\text { No evidence } \\
\text { of tumor }\end{array}$ & $\begin{array}{l}\text { No residual tumor } \\
\text { or ulcer, only } \\
\text { whitening of } \\
\text { mucosa or } \\
\text { telangiectasia }\end{array}$ & Negative & No disease & - & - & - & - \\
\hline $\begin{array}{c}\text { Li et al. (2015) } \\
\text { [24] }\end{array}$ & $\begin{array}{l}\text { No palpable } \\
\text { tumor }\end{array}$ & $\begin{array}{l}\text { No visible lesion } \\
\text { other than flat } \\
\text { scar }\end{array}$ & - & $\begin{array}{l}\text { Similar to MRI } \\
\text { (when MRI not } \\
\text { performed) }\end{array}$ & $\begin{array}{l}\text { No residual } \\
\text { tumor }\end{array}$ & $\begin{array}{l}\text { Similar to } \\
\text { MRI (when } \\
\text { MRI, CT not } \\
\text { performed) }\end{array}$ & - & - \\
\hline
\end{tabular}

developed by Dworak et al. (although in its seminal work Dworak did not find any patients with TRG4 among the 17 evaluated specimens) [14]. In a reduced number of studies [15], pCR was equivalent with grade 3 according to the histological criteria for the assessment of response to chemotherapy/RT released by the Japanese Society for Cancer of the Colon and Rectum [16]. Irrespective the grading/ scoring system used for its assessment, pCR is a clear entity, characterized by the absence of viable tumor cells on the specimen of rectal resection, after neoadjuvant CRT (Figures 1-3).

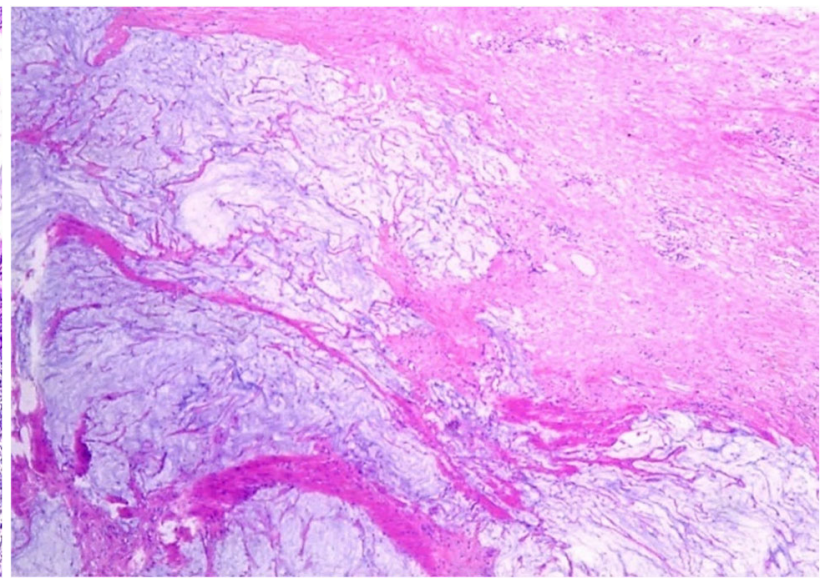

Figure 2 - Complete tumor regression (TRG0/pCR) with extensive pools of extracellular, acellular mucin also known as colloid response. The presence of acellular mucin pools in pCR patients does not affect prognosis. HE staining, $\times 40$.

In a meta-analysis of 14 studies including patients that underwent RS after neoadjuvant CRT, the pooled prevalence of pCR was $16 \%$ [9]. The rate of pCR ranged between $8 \%$ and $29 \%[6,7,17-21]$, mainly depending on the initial clinical T (cT) stage and the type of neoadjuvant therapy.

Unfortunately, pCR cannot be established before rectal resection. Thus, the results achieved by neoadjuvant CRT are evaluated by digital rectal examination (DRE), rectoscopy (with or without biopsy) and radiological methods [such as computed tomography (CT) scan, magnetic resonance imaging (MRI) and/or positron-emission tomography (PET)/ $\mathrm{CT}$. The term that was coined for the disappearance or rectal tumor with virtual absence of viable malignant cells is cCR. cCR represents a surrogate parameter used mainly when rectum-sparing approaches are considered after neoadjuvant CRT [21-23].

Although many studies are discussing the management of patients with $\mathrm{RC}$ that experienced $\mathrm{cCR}$ after neoadjuvant CRT, there is a lack of consensus on the definition of cCR (Table 1) 
Assessment of clinical and pathological complete response after neoadjuvant chemoradiotherapy in rectal...

\begin{tabular}{|c|c|c|c|c|c|c|c|c|}
\hline Study & DRE & Endoscopy & Biopsy & CT scan & MRI & ERUS & PET/CT & CEA \\
\hline $\begin{array}{l}\text { Dalton et al. } \\
(2012)[11]\end{array}$ & Normal & $\begin{array}{l}\text { No residual tumor } \\
\text { or ulcer (even if } \\
\text { biopsy finding } \\
\text { negative). Only } \\
\text { residual scar }\end{array}$ & $\begin{array}{c}\text { Negative from } \\
\text { previous tumor } \\
\text { site/ } \\
\text { residual scar }\end{array}$ & - & $\begin{array}{l}\text { Significant } \\
\text { tumor } \\
\text { regression, with } \\
\text { little evidence of } \\
\text { residual tumor } \\
\end{array}$ & - & $\begin{array}{l}\text { No } \\
\text { evidence } \\
\text { of tumor }\end{array}$ & - \\
\hline $\begin{array}{l}\text { Smith et al. } \\
(2012)[25]\end{array}$ & $\begin{array}{c}\text { No palpable } \\
\text { tumor }\end{array}$ & $\begin{array}{l}\text { No other lesion } \\
\text { than a flat scar }\end{array}$ & $\begin{array}{c}\text { Selective } \\
\text { biopsy (scar) }\end{array}$ & - & - & - & - & - \\
\hline $\begin{array}{l}\text { Glynne-Jones } \\
\text { et al. (2017) } \\
{[26]}\end{array}$ & $\begin{array}{l}\text { No palpable } \\
\text { tumor or } \\
\text { irregularity }\end{array}$ & $\begin{array}{l}\text { No other lesion } \\
\text { than flat scar, } \\
\text { telangiectasia, or } \\
\text { mucosal whitening }\end{array}$ & $\begin{array}{l}\text { Negative } \\
\text { biopsy from } \\
\text { the scar }\end{array}$ & - & $\begin{array}{c}\text { No residual } \\
\text { tumor at } \\
\text { primary site or } \\
\text { lymph nodes }\end{array}$ & $\begin{array}{l}\text { Similar to } \\
\text { MRI (when } \\
\text { MRI not } \\
\text { performed) }\end{array}$ & - & $\begin{array}{l}\text { Normalized } \\
\text { after CRT }\end{array}$ \\
\hline $\begin{array}{l}\text { Maas et al. } \\
(2011) \text { [22] }\end{array}$ & $\begin{array}{l}\text { No palpable } \\
\text { tumor }\end{array}$ & $\begin{array}{l}\text { No residual tumor } \\
\text { or only a small } \\
\text { residual } \\
\text { erythematous } \\
\text { ulcer or scar }\end{array}$ & $\begin{array}{c}\text { Negative } \\
\text { biopsies from } \\
\text { the scar/ } \\
\text { ulcer/former } \\
\text { tumor location }\end{array}$ & - & $\begin{array}{l}\text { No residual } \\
\text { tumor or } \\
\text { residual fibrosis } \\
\text { only or residual } \\
\text { wall thickening } \\
\text { due to edema } \\
\text { and no } \\
\text { suspicious } \\
\text { lymph nodes }\end{array}$ & - & - & - \\
\hline $\begin{array}{l}\text { Lai et al. } \\
\text { (2016) [27] }\end{array}$ & $\begin{array}{l}\text { No tumor, } \\
\text { mucosal } \\
\text { irregularity, or } \\
\text { ulceration }\end{array}$ & $\begin{array}{c}\text { No tumor, } \\
\text { mucosal } \\
\text { irregularity, or } \\
\text { ulceration. Only } \\
\text { mucosal whitening } \\
\text { and telangiectasia }\end{array}$ & s. & $\begin{array}{l}\text { Similar to MRI } \\
\text { (when MRI not } \\
\text { performed) }\end{array}$ & $\begin{array}{l}\text { No residual } \\
\text { rectal disease } \\
\text { or extrarectal } \\
\text { disease }\end{array}$ & $\begin{array}{l}\text { Similar to } \\
\text { MRI (when } \\
\text { MRI, CT not } \\
\text { performed) }\end{array}$ & - & - \\
\hline
\end{tabular}

cCR: Clinical complete response; CEA: Carcinoembryonic antigen; CRT: Chemoradiation therapy; CT: Computed tomography; DRE: Digital rectal examination; ERUS: Endorectal ultrasound; MRI: Magnetic resonance imaging; PET: Positron-emission tomography.

Due to the different definitions of the $\mathrm{cCR}$, the rate of this observation varies largely between different series. Irrespective the rate of cCR rates, it was hypothesized that most of these patients will experience pCR. Unfortunately, between $5 \%$ and $53 \%$ of patients with cCR had still viable tumor cells, depending on the modality of cCR assessment $[28,29]$. By contrary, between $8.3-16.6 \%$ of patients who did not fulfill the criteria of cCR had pCR at pathological examination of the resected specimen $[8,11,28,29]$. These data reveal that there is not an "overlapping" between $\mathrm{cCR}$ and $\mathrm{pCR}$, mainly depending on the modality of $\mathrm{cCR}$ assessment [30-32].

Thus, in the studies that do not use biopsy assessment, up to $53 \%$ of patients with cCR do not have pCR on rectal resection specimens [29]. In a study of Habr-Gamma, which evaluated 360 patients with RC who received neoadjuvant CRT, out of 99 patients who were considered as having cCR based on DRE and rectoscopy, five (5\%) were wrongly classified. By contrary, among 261 patients without cCR, $24(9.1 \%)$ had pCR on histological examination of the resection specimen [28]. Thus, DRE associated with rectoscopy had a sensitivity of $79.6 \%$ in detecting $\mathrm{pCR}$, and a specificity of $97 \%$. A similar specificity (97\%) of macroscopic assessment in prediction of $\mathrm{pCR}$ was reported by Smith et al., but in their study the sensitivity of macroscopic evaluation was much lower (26\%) [33]. Guillem et al. revealed that DRE and rectoscopy underestimated the response to neoadjuvant CRT in majority of their patients, being able to correctly identify pCR in only three out of $14(21 \%)$ patients [30]. In 166 patients with LARC who were treated by neoadjuvant CRT followed by RS, rectoscopy after neoadjuvant CRT had a positive-predictive value of $88.2 \%$, a negative-predictive value of $53.8 \%$ and an accuracy of $85.5 \%$ [34]. Patients in whom rectoscopy showed residual ulcers after neoadjuvant CRT had viable malignant cells at pathological examination of the resection specimen in $65 \%$ cases, while only $46 \%$ of those with fibrotic scars had residual tumor on pathology report [34]. Combining endoscopy with biopsy, the prediction rate for pCR increased to $77 \%$ [34].

Even in the studies that used biopsy from the residual scars/ulcers/tumors, up to $78 \%$ of patients with negative biopsies still have residual tumor on the resected specimen [34]. Although biopsy alone offered a positive-predictive value of $100 \%$, its negative-predictive value was only $21.4 \%$ and accuracy $44.6 \%$ [34]. That could be explained by the fact that residual scar/ulcer area may not be representative for the potential residual tumor after neoadjuvant CRT. Thus, Hayden et al. demonstrated that among the patients without pCR almost $50 \%$ had malignant cells outside the visible ulcer margin (median distance was $1 \mathrm{~cm}$ ) or in the absence of a residual ulcer [36]. Furthermore, only 13\% and $56 \%$ of patients with ypT2-4 had residual malignant cells after CRT in mucosa and submucosa, respectively, while $98 \%$ had residual cells in the muscularis propria [37]. Because biopsy samples are frequently taken from mucosa and submucosa, the risk of a false-negative pCR is very high. Based on such information, as well as those derived from other studies [38, 39], a recent consensus released by experts in RC treatment did not recommend the routinely use of biopsy sampling to establish the pCR due to the risk of false-negative findings and a lack of evidence of value, especially when DRE, endoscopy and MRI criteria for cCR are all fulfilled [40-42].

Although pelvic MRI has an increased ability to correctly assess the $\mathrm{T}$ stage before treatment, its usefulness in evaluation of pCR after neoadjuvant CRT has been a subject of debate during the last decade. The main pitfall after neoadjuvant CRT is represented by the development of fibrosis which decreases the ability of MRI to differentiate between residual tumor and fibrosis. Moreover, tumor may still exist within a scar [43]. Thus, in a study published in 2011, Kuo et al. showed that MRI had a positive-predictive value of $86.4 \%$, a negative-predictive value of $33.3 \%$ and accuracy of $82.5 \%$ in predicting pCR after neoadjuvant CRT [34]. Based on these results the authors stated that MRI 
might not be a useful predictor of pCR after neoadjuvant CRT in patients with LARC [34]. During the last years, the addition of diffusion-weighted (DW) to MRI improved the ability of MRI to predict pCR [44, 45]. In a study published in 2018, Horvat et al. revealed that combined T2-weighted and DW imaging achieved a sensitivity of $84 \%$, a specificity of $56 \%$, a positive-predictive value of $30 \%$ and a negative-predictive value of $94 \%$ for pCR assessment [43]. In this study, MRI-based radiomics features of the primary tumor were also investigated to assess their predictive value in the diagnosis of pCR. Radiomics analysis involves computer-based extraction of a large number of quantitative features and has potential for aiding clinical decision making $[43,46]$. In their study, radiomics features of the primary tumor were able to significantly increase the specificity (to $91 \%$ ) and positive-predictive value (to $72 \%$ ), while sensitivity and negative-predictive value for pCR were $100 \%$ [area under the curve (AUC) of 0.93] [43]. Moreover, recent studies revealed that MRI radiomics features of the mesorectum have also been associated with increased performance in predicting pCR [47, 48] after neoadjuvant CRT in patients with LARC. By using eight MRI radiomic features of the mesorectal fat, Jayaprakasam et al. were able to develop a predictive support vector machines model that achieved a diagnostic accuracy for pCR of $83.9 \%$, a sensitivity of $78 \%$, a specificity of $85.1 \%$, a negative predictive value of $94.9 \%$, a positive predictive value of $52.5 \%$ and an AUC of 0.89 [47]. Thus, in present, DW-MRI, associated with MRI-based radiomics of the primary tumor and mesorectal fat can predict pCR with high accuracy, representing an important complementary tool to the DRE and rectoscopy.

In an early, small sample size study exploring the usefulness of PET/CT in evaluation of pCR after neoadjuvant CRT, Martoni et al. found that Fluorodeoxyglucose (FDG)PET/CT has limited predictive value for pCR achievement [13]. Similar to this study, Calvo et al. [49] and Capirci et al. [50] revealed that PET/CT could be seen only as a complementary tool in assessing the response to neoadjuvant CRT. More specifically, Vliegen et al. showed that although PET/CT may predict tumor response to neoadjuvant CRT, its accuracy in predicting pCR is limited [51]. A study from Memorial Sloan-Kettering Cancer Center published in 2013 which evaluated 121 patients with LARC treated with neoadjuvant CRT revealed that the absence of FDG uptake after neoadjuvant CRT has not been equivalent with pCR [21]. The PET/CT evaluation had a sensitivity of $54 \%$, specificity of $66 \%$, positive predictive value of $30 \%$, negative predictive value of $84 \%$ and an AUC of 0.64 in predicting pCR after neoadjuvant CRT. The ability of CT scan in predicting pCR has also been low, with a sensitivity of $19 \%$, specificity of $95 \%$, positive predictive value of $50 \%$ and negative predictive value of $81 \%$ [21]. Consequently, the authors concluded that neither PET/CT, nor CT scan predict pCR with enough accuracy to be considered clinically useful for treatment decision after neoadjuvant CRT in patients with LARC [21]. A study published in 2019 by Sorenson et al. re-emphasized the decreased value of PET/CT (performed at baseline and 6-8 weeks after neoadjuvant CRT) in predicting pCR after neoadjuvant CRT in LARC patients [20]. In their study, $\mathrm{PET} / \mathrm{CT}$ was rather useful in identification of poor responders to neoadjuvant CRT, since more than $85 \%$ of patients with a post-CRT standardized uptake value (SUV) $\max$ higher than 4.3 will not achieve pCR [20]. They concluded that future multicenter prospective trials combining DRE with rectoscopy and PET/CT could provide more robust data about the usefulness of post-CRT PET/CT to select patients for RS or organ-sparing approaches [20].

Even the accuracy of histological examination of resected specimen in the detection of pCR was questioned by some authors. Thus, Chen et al. [52] extracted deoxyribonucleic acid (DNA) from 26 specimens deemed as pCR after pathological examination and used standard and highlysensitive polymerase chain reaction (PCR) techniques to identify the presence of tumor-specific p53 and Kirsten rat sarcoma viral oncogene homologue (KRAS) mutations. They found evidence of residual tumor cells in $7.7 \%(2 / 26)$ of cases [52].

Because the currently available methods are not able to predict pCR with $100 \%$ accuracy even in patients with cCR, the assessment of factors that are significantly associated with the occurrence of pCR became tremendously important. Different clinico-pathological factors, neoadjuvant treatment schedules and molecular features have been reported to be associated with the response to neoadjuvant CRT. Prediction of pCR should take into account these variables, which are useful for advising patients on prognosis after neoadjuvant CRT and treatment options [7].

\section{ㅁ Prognostic factors for PCR}

The most frequently reported clinical predictors of $\mathrm{cCR}$ were cT stage, tumor volume and the extent of rectum circumference involvement [53-56].

\section{Clinical stage at baseline}

Among the factors that were associated with the occurrence of CR, cT stage was an independent prognostic for both $\mathrm{cCR}$ and $\mathrm{pCR}$. Thus, Peng et al. revealed that $\mathrm{cT}$ stage was an independent predictor for cCR [5] and the meta-analysis of Maas et al. showed that pCR was significant more frequently observed in cT1/T2 patients than in cT3/T4 patients [9]. Furthermore, Hasan et al. [6] evaluated the results of neoadjuvant CRT followed by surgery in 5086 patients with LARC, revealing that the lower cT stage, the significantly higher was the chance of pCR [cT1/T2 vs. cT3: odds ratio $(\mathrm{OR})(95 \% \mathrm{CI})=0.60(0.41-0.87), p=0.01$; cT1/T2 vs. cT4: OR $(95 \%$ CI $)=0.25(0.13-0.49), p<0.001]$. In this study, cT stage was the strongest predictor of $\mathrm{pCR}$ in multivariate analysis [6]. In another study, cT stage was the only predictive factor independently associated with pCR achievement (in multivariate analysis), although clinical $\mathrm{N}(\mathrm{cN})$ stage and maximum diameter of the tumor have also been associated with pCR in univariate analysis (but not in multivariate analysis) [56]. So far, there are no strong evidence to support the predictive value of $\mathrm{cN}$ stage [9] and maximum tumor diameter at baseline for $\mathrm{pCR}$ achievement.

\section{Tumor size at baseline}

However, since the late ' $90 \mathrm{~s}$, it has been suggested that the volume of $\mathrm{RC}$ at baseline is as an even stronger predictor of tumor response to neoadjuvant CRT than $\mathrm{cT}$ stage $[57,58]$. In a small study, which intended to evaluate the feasibility of a high-dose rate endorectal brachytherapy boost after external beam RT in elderly patients with rectal 
cancer who were unfit for surgery, the volume of the RC and the thickness of the tumor at baseline were the only predictive factor associated with cCR in univariate analysis ( $p=0.005$ and $p=0.02$, respectively) [55]. Moreover, patients whose tumor volume was lower than $20 \mathrm{~cm}^{3}$ experienced a $74 \%$ sustained response rate at two years, significantly higher $(p=0.007)$ than those observed in patients with larger tumors [55]. Recently, a larger study that included 187 patients with LARC treated by neoadjuvant CRT and RS, revealed that $44(23.5 \%)$ patients had pCR on the resected specimen [59]. In multivariate analysis, the volume of RC less than $39.5 \mathrm{~cm}^{3}$ was the only independent predictive factor for $\mathrm{pCR}$ occurrence $(p<0.01$ by logistic regression model and $p=0.026$ by Bayesian independent test) [59]. The degree of circumferential extension of the RC could also represent a surrogate parameter for the volume of the rectal tumor. In a paper published in 2007, Das et al. revealed that a circumferential involvement of the rectum less than $60 \%$ was independently associated with a higher rate of pCR [54].

In 2011, van Stiphout et al. developed a predictive model for $\mathrm{pCR}$ incorporating $\mathrm{cT}$ stage, $\mathrm{cN}$ stage and tumor length, which achieved an AUC of the receiver operating characteristic (ROC) curve of 0.61 in the training dataset and an AUC of 0.69 in the validation dataset [60]. By adding pre- and post-CRT PET/CT specific data as postCRT SUV $V_{\max }$ and relative change of $\mathrm{SUV}_{\max }$ to the tumor length, they achieved a predictive model that performed significantly better in predicting $\mathrm{pCR}(\mathrm{AUC}=0.83 ; p<0.01$ in training dataset and $\mathrm{AUC}=0.86 ; p=0.056$ in validation dataset) [60]. To identify the patients with highest chance to achieve pCR as early as possible, the same group developed a nomogram including the following parameters: cT stage, $\mathrm{cN}$ stage, intermediate maximum diameter, and response index of SUV mean; the latter two parameters were evaluated based on PET/CT performed before starting CRT and during CRT (15 days after its start) [56]. This model was able to divide the patients in three groups according to the chance of achieving $\mathrm{pCR}$, based on the percentages released by the nomogram. Thus, patients with a higher than $53 \%$ score had a significantly increased probability of pCR occurrence, compared to those in the other two groups $(100 \%$ vs. $21.3 \%$ vs. 7.35 , respectively, in the training dataset, and $66.7 \%$ vs. $30.8 \%$ vs. $13 \%$, respectively, in the validation dataset) [56]. These early estimation of pCR is important to avoid over-treatment of poor responders, that most probably do not have any benefit from intensified therapy.

\section{Pathological type of RC}

Pathological type of $\mathrm{RC}$ has recently been demonstrated as a predictor for $\mathrm{pCR}$. Thus, a study that included patients with LARC (from three prospective clinical trials) assessed the predictive implication of mucinous adenocarcinoma (MAC) on the rate of pCR achievement after neoadjuvant treatment. Although in patients who received only neoadjuvant chemotherapy the rate of $\mathrm{pCR}$ was not significantly different between MAC group and non-MAC group ( $0 \%$ vs. $13.2 \%$, respectively; $p=0.11)$, among patients treated with neoadjuvant CRT (irrespective the chemotherapy regimen) the rate of $\mathrm{pCR}$ was statistical significantly higher in non-MAC group than in the MAC group $(27.3 \%$ vs. $11 \%$, respectively; $p=0.03$ ) [61].

\section{Type of neoadjuvant therapy}

Undoubtably, the regimen of neoadjuvant therapy plays an important role in the response rate of patients with LARC. Since the late ' $80 \mathrm{~s}$, it was observed that neoadjuvant RT is able to produce pCR in some patients with RC. Thus, a randomized trial, published in 1989, which evaluated preoperative RT (34.5 Gy divided in 15 doses) in patients with $\mathrm{RC}$ revealed that in the preoperative RT (followed by surgery) arm five out of 231 patients had pCR (2.1\%) [62]. A slightly higher rate of pCR (4.4\%) after neoadjuvant RT (31.5 Gy) was reported in 1990, by Horn et al., in a similar randomized trial performed in Norway [63]. Moreover, in 1997, Berger et al. showed that higher doses of neoadjuvant RT, tumor differentiation and prolonged interval between RT and surgery were predictive factors for RC downstaging [64]. However, they were not able to identify the predictors of pCR, mainly due to the small number of patients (nine out of 167 patients $-5 \%$ ) which experienced this outcome [64].

In the late ' $90 \mathrm{~s}$, it was hypothesized that the addition of concurrent chemotherapy to preoperative RT may improve outcomes in patients with LARC. In 1998, a retrospective study that evaluated the rate of postoperative complications after neoadjuvant RT (45 Gy in 25 fractions) and concurrent continuous infusion of 5-Fluorouracil (5-FU) followed by RS, reported the achievement of pCR in $27 \%$ patients with LARC [65]. A randomized trial whose results were published in 2006 that compared the outcomes of preoperative RT alone (45 Gy in 25 fractions) to those achieved by the same RT regimen associated with 5-FU/Leucovorin reported similar results [66]. All the patients underwent RS 3-10 weeks after neoadjuvant treatment and subsequent adjuvant chemotherapy with 5-FU/Leucovorin [66]. A pCR was significant more frequently achieved in neoadjuvant CRT group than in neoadjuvant RT alone group $(11.4 \%$ vs. 3.6\%, respectively; $p<0.05$ ) [66]. Moreover, the fiveyear LRR was significantly lower after neoadjuvant CRT than after RT alone ( $8.1 \%$ vs. $16.5 \%$, respectively; $p<0.05)$, although the OS rates were similar in the two groups [66]. A randomized phase III clinical trial revealed that preoperative RT associated with Capecitabine determined similar three-year LRRs, five-year disease-free survival (DFS) and OS rates as neoadjuvant RT combined with 5-FU continuous infusion [67]. In the same study, the addition of Oxaliplatin did not improve the long-term outcomes, but significantly increased the incidence of overall grade 3-5 toxicities [67].

To evaluate the long-term outcomes achieved by preoperative CRT vs. postoperative CRT, Sauer et al. performed a randomized clinical trial in which patients were randomly assigned to either preoperative RT (5040 cGy) and two cycles of continuous infusion 5-FU followed by RS (six weeks after CRT) and subsequent four cycles of continuous infusion 5-FU or RS followed by identical CRT [18]. Although the five-year OS rates were similar in the two groups $(76 \%$ vs. $74 \%$, respectively; $p=0.80)$, the five-year cumulative incidence of local recurrence (LR) was significantly lower in the preoperative CRT group than in the postoperative CRT group ( $6 \%$ vs. $13 \%$, respectively; $p=0.006$ ) [18].

Patients who received modified 5-FU, Leucovorin and Oxaliplatin 6 (mFOLFOX6) during the interval between 
neoadjuvant CRT and surgery experienced significantly higher rates of $\mathrm{pCR}$ than those who received only CRT [68]. These initial results raised the question if total neoadjuvant therapy (TNT) could further improve the longterm outcomes in patients with LARC, as well as the rate of pCR.

The advent of TNT in the last decade, meaning the use of either induction chemotherapy before CRT or consolidation chemotherapy after standard CRT seems to increase the likelihood of achieving pCR. A recent metaanalysis reported a pooled pCR rate of $22.4 \%$ (95\% CI: 19.4-25.7) in patients treated with TNT [69]. Based on the reported results of the 10 studies which compared TNT with standard neoadjuvant CRT, TNT increased by $39 \%$ the likelihood of pCR (1.40, 95\% CI: $1.08-1.81, p=0.01)$ [69]. Moreover, the addition of six cycles of Folinic Acid (Leucovorin), 5-FU, Irinotecan, Oxaliplatin (FOLFIRINOX) before CRT significantly improved three-year DFS compared with CRT alone (76\% vs. 69\%, respectively; $p=0.034$ ) [70].

\section{Interval between neoadjuvant CRT and surgery}

Optimal time interval between the end of neoadjuvant CRT and the development of pCR has not been identified. A monocentric study published in 2009 assessed the predictive factors for pCR after neoadjuvant CRT, identifying extended time interval (more than eight weeks) between the end of CRT and surgery as the only independent predictor for pCR achievement [71]. An up-dated evaluation of patients from the same center revealed that a prolonged interval (more than eight weeks) between the end of CRT and RS was associated with a decreased three-year LRR, compared to those observed in patients operated after a shorter interval (less than eight weeks) ( $1.2 \%$ vs. $10.5 \%$, respectively; $p=0.04)$ [72]. Nevertheless, the optimal cut-off for the "prolonged" interval between CRT and surgery has been differently reported by other authors. A retrospective analysis of 23747 patients with RC included in National Cancer Database (NCDB) between 2006 and 2011 found the time interval between the end of CRT and RS longer than six weeks as an independent predictor for the achievement of $\mathrm{pCR}$, the highest rates of $\mathrm{pCR}$ being achieved in patients operated at more than eight weeks [7]. A Dutch study revealed that the highest incidence of $\mathrm{pCR}$ was achieved in patients operated 15-16 weeks after the start of neoadjuvant CRT [73]. Moreover, the use of TNT dramatically changed the interval between the start of neoadjuvant therapy and subsequent evaluation of CR. A phase II trial published in 2015 revealed that patients who received six cycles of mFOLFOX6 after neoadjuvant CRT had the highest rate of pCR (38\%), being operated at 26 weeks after the start of neoadjuvant therapy [68]. Consequently, a recent consensus on key outcome measures for organ preservation after CRT in patients with $\mathrm{RC}$ considered that it is not possible to establish a specific time point for assessing cCR. However, because pCR cannot undoubtedly be established by preoperative evaluation, in patients considered for rectumsparing approaches the consensus recommended to evaluate the occurrence of cCR in a two-step manner. Thus, in patients with RC that might underwent an organ-sparing approach was recommended a first assessment at 12 weeks after starting of short-course RT or CRT and a subsequent evaluation at 16-20 weeks after the initiation of neoadjuvant treatment. Patients without down-staging at 12 weeks should be immediately referred for RS to ensure oncological safety. The good responders (identified at 12 weeks) should be re-evaluated 4-8 weeks later, recommending rectumsparing approaches in those who achieved a cCR at that time point [40]. In patients treated with TNT, the optimal interval between the start of neoadjuvant therapy and the time of cCR assessment is still unclear, especially due to the various durations of different TNT schemes. However, an early response evaluation is needed to identify the poor responders that should be referred to RS for oncological safety reasons. For good responders, who might benefit from completing the scheduled TNT, the evaluation of cCR could be done at 4-8 weeks after the end of TNT, but even in these patients close monitoring during the neoadjuvant treatment is mandatory [40].

\section{Molecular features of RC}

Apart from clinic and pathological factors, molecular profile of RC is related with treatment response [74]. Most colorectal carcinomas are sporadic, but sometimes the appearance of these types of tumors in a syndromic context can be demonstrated by molecular surrogate immunohistochemical (IHC) tests. Sometimes, colorectal carcinomas may demonstrate microsatellite instability (MSI), a functional manifestation of mismatch repair (MMR) protein deficiency. MMR IHC enables pathologists to assess the expression status of the four proteins [MutL homolog 1 (MLH1), PMS1 homolog 2, MMR system component (PMS2), MutS homolog 2 (MSH2) and MutS homolog 6 (MSH6)]. As a rule, the presence of all four proteins signifies a microsatellite stable tumor, although exceptions exist; whereas staining loss indicates MMR deficiency with the pattern suggesting the defective gene. However, MMR IHC is not considered genetic testing since it evaluates protein expression. Most colorectal carcinomas are MMR stable (Figures 4-7) with retained nuclear expression for the MMR immunomarkers. A recent study showed that MSI status has been an independent prognostic factor for $\mathrm{pCR}$ in patients with LARC [6]. Among the 636 patients with MSI-positive RC the prevalence of pCR was 5.9\%, statistical significantly lower than those observed in 4450 patients with MSI-negative RC $(8.9 \%, p=0.01)$. The difference remained also significant even after propensity-score matching in multivariate analysis $[\mathrm{OR}(95 \% \mathrm{CI})=0.65$ (0.43-0.96)] [6]. This observation emphasizes the importance of initial testing for MSI status of patients with RC, especially when a rectum-sparing approach is considered (usually due to the advanced age and comorbid conditions of the patient).

Novel biomarkers that were associated with pCR were lower levels of circulating vascular endothelial growth factor receptor 3 (VEGFR3), epidermal growth factor receptor (EGFR) and cyclooxygenase-2 (COX-2) in pretreatment plasma samples of patients with LARC [75]. A combination of these three circulating biomarkers using logistic regression generated an AUC of 0.869 (with a sensitivity of $43 \%$ at $95 \%$ specificity) in prediction of pCR [75].

Clinical implication of pCR is of paramount importance because the survival rates achieved by RS in these patients are significantly higher than those observed in patients 
without $\mathrm{pCR}[9,76]$. Moreover, recent studies suggested that in selected patients with $\mathrm{pCR}$ the long-term outcomes achieved by local excision (LE) or watch and wait (WW) approach are similar to those reported after RS.

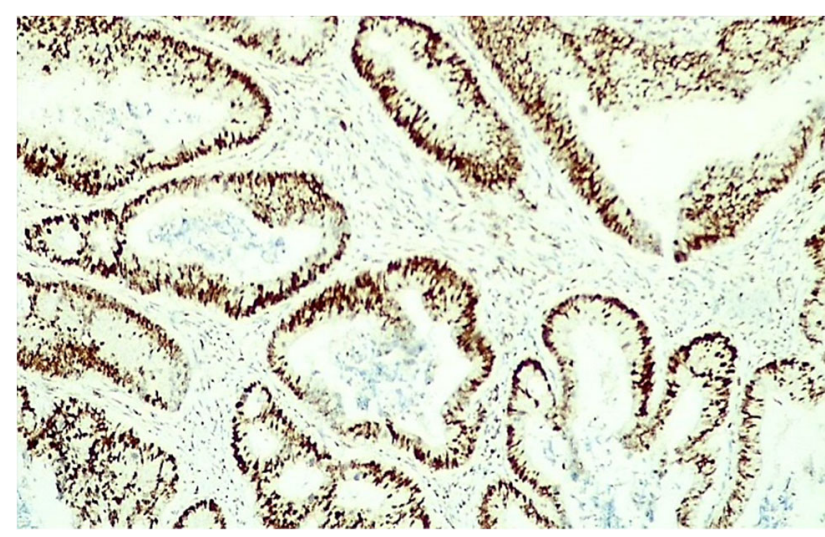

Figure 4 - Colonic adenocarcinoma with strong, diffuse nuclear staining for MLH1. Anti-MLH1 antibody immunostaining, $\times 200$. MLH1: MutL homolog 1.

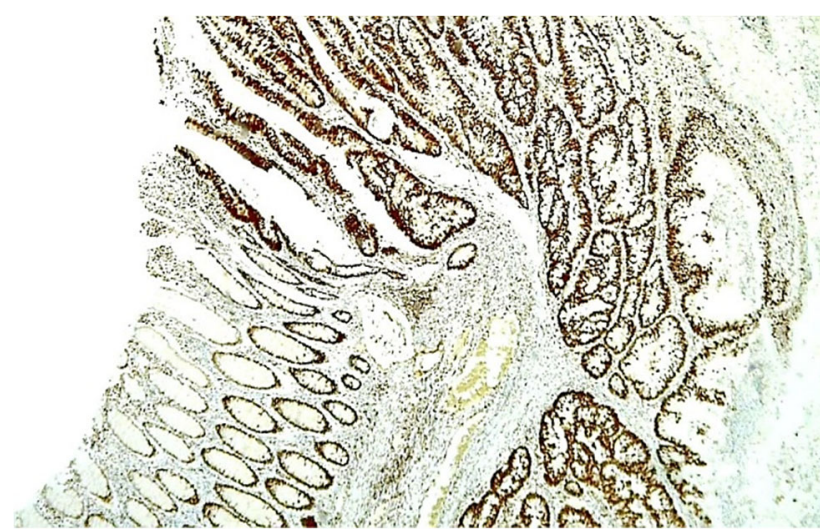

Figure 6-MMR stable colonic adenocarcinoma with retained staining for MSH2. The colonic mucosa in the vicinity of the neoplastic proliferation provides an ideal positive internal control. Anti-MSH2 antibody immunostaining, $\times 100$. MMR: Mismatch repair; MSH2: MutS homolog 2.

Because current clinical and paraclinical methods are not able to predict pCR with $100 \%$ specificity and sensitivity, the treatment strategy is chosen based on the parameters that define cCR. Thus, the accurate evaluation of cCR after neoadjuvant CRT is of tremendous importance, especially in patients who refuse RS, or having a poor performance status which is associated with high-risk RS. In such patients, the accurate evaluation of cCR is crucial, because alternative strategies consist in LE or WW approach, both of them omitting TME which is still considered the standard approach to RC. A recent international consensus on key outcome measures for organ preservation after (chemo)radiotherapy in patients with RC [40] has chosen the Amsterdam/ Maastricht criteria for defining cCR [22].

Although the current studies assessing the outcomes of organ-preserving strategies are heterogeneous in terms of selection criteria for different treatments and reported endpoints, thus limiting the accuracy of data interpretation and comparison between studies [40], international guidelines already allow less-radical management in selected patients with cCR after neoadjuvant CRT [26, 77, 78]. Further on are presented the results achieved by current approaches in patients with cCR after neoadjuvant CRT.

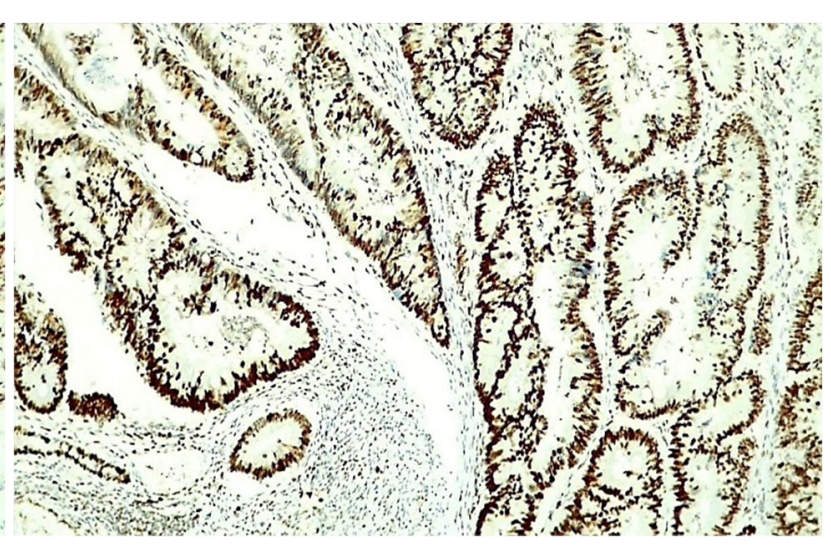

Figure 5 - MMR stable colonic adenocarcinoma with strong nuclear staining for PMS2. Anti-PMS2 antibody immunostaining, $\times 200$. MMR: Mismatch repair; PMS2: PMS1 homolog 2, mismatch repair system component.

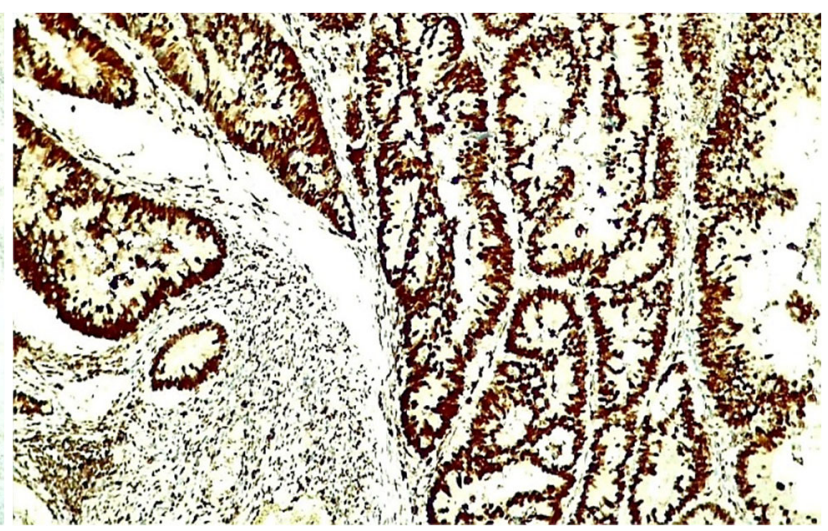

Figure 7 - MMR stable colonic adenocarcinoma with retained staining for MSH6. Anti-MSH6 antibody immunostaining, $\times 200$. MMR: Mismatch repair; MSH6: MutS homolog 6.

\section{a Treatment strategies in patients with CCR}

In present, for patients who achieved cCR after CRT, three approaches could be considered: (i) RS meaning rectal resection with TME - is still considered the standard treatment; (ii) LE which consists in full-thickness excision of the tumor bed with a $1 \mathrm{~cm}$ safety margin and closure of the rectal wall - represents a surgical alternative to RS for selected patients; (iii) WW strategy consisting in close follow-up of these patients is a non-surgical approach for patients who achieved cCR after neoadjuvant CRT, aiming to avoid surgery in elderly or high-risk patients. Because there are few randomized clinical trials with various designs which compared the results of these strategies, the optimal approach for these patients is still unclear, each of these strategies having advantages, limitations, and drawbacks.

\section{RS with TME}

RS still represents the "gold standard" approach to RC patients.

\section{Short-term outcomes after RS in patients with pCR}

Although initially has been supposed that RS is associated with lower morbidity and mortality rates in 
patients who achieved pCR after neoadjuvant CRT compared to those without $\mathrm{pCR}$, the available data are still conflicting. In 2009, Stelzmueller et al. found a higher rate of major morbidity (Clavien-Dindo III-IV) in patients who experienced tumor down-staging after neoadjuvant CRT than in those without down-staging (26.6\% vs. 8.8\%, respectively; $p<0.05$ ), although the achievement of $\mathrm{pCR}$ was not correlated with significantly higher morbidity rates [79]. Maggiori et al. revealed that overall morbidity rates were not statistical significantly different between laparoscopically-resected patients who achieved pCR after neoadjuvant CRT and those who did not achieve pCR (36\% vs. $51 \%$, respectively, $p=0.20$ ) [29]. However, in patients with pCR the rates of clinical anastomotic leakage $(9 \%$ vs. $29 \%$, respectively; $p=0.02)$ and major morbidity $(6 \%$ vs. $22 \%$, respectively; $p=0.04$ ) were significantly lower compared to those observed in patients without pCR [29]. On the other hand, neoadjuvant CRT itself increases the risk of anastomotic leakage [80]. Duldulao et al. did not find significantly different morbidity rates after RS between patients who achieved $\mathrm{pCR}$ and those without $\mathrm{pCR}$, either for overall postoperative complications ( $41 \%$ vs. 35\%, respectively; $p=0.72)$, or major postoperative complications (18\% vs. 8\%, respectively; $p=0.16$ ) [81]. A study which evaluated 23747 patients with RC who underwent neoadjuvant CRT and RS, revealed (after propensityadjusted analysis) that mortality rates after RS in patients with LARC who experienced pCR after neoadjuvant CRT were similar to those reported in patients without $\mathrm{pCR}$ ( $0.7 \%$ for each group; $p=0.119)$ [7]. The same analysis of patients included in NCDB between 2006 and 2011 found that length of hospital stay was slightly (but statistically significant) shorter in patients who experienced pCR than in those without pCR (7.26 days $v s .7 .49$ days, respectively; $p=0.045$ after propensity-adjusted analysis) [7]. In the study of Maggiori et al., length of hospital stay was also significantly shorter in resected patients with pCR than in those without pCR (nine days vs. 12 days, respectively; $p=0.01$ ) [29].

\section{Long-term outcomes after RS in patients with $p C R$}

Even in the first decade of the third millennium few authors reported better local control, improved DFS and OS after RS in patients who achieved pCR following neoadjuvant CRT [82-84]. A meta-analysis of Maas et al. reported the results achieved by $\mathrm{RS}$ in patients operated after neoadjuvant CRT [9]. After a median follow-up of 46 months, the data about LR were available only for 455 patients with pCR; in these patients LR was observed only in 12 cases (five-year LRR was $2.8 \%$ ). Out of 419 patients with pCR and available data about disease recurrence, the disease recurred in 61 patients (five-year DFS was $83.3 \%$ ). In 465 patients with pCR and available data on OS, there were 53 death during follow-up interval, with a five-year OS rate of $87.6 \%$ [9]. In their counterpartners without pCR who underwent RS, both five-year DFS and OS rates were significantly lower $(65.6 \%$ and $76.4 \%$, respectively) than those observed in patients with pCR $(p<0.0001)$. Furthermore, five-year LRR was significantly higher in patients without pCR $(9.7 \%)$, than in patients with pCR $(p<0.0001)$ [9]. In 2012, Kuo et al. published a retrospective analysis of 161 patients who underwent RS after neoadjuvant CRT, revealing that no one patient with $\mathrm{pCR}$ developed LR after RS [34]. However, $8 \%$ of patients with pCR after neoadjuvant CRT developed distant metastases after RS, even in the absence of LR [34].

\section{Local excision}

LE could be performed by conventional transanal approach, by transanal endoscopic microsurgery (TEM) or by transanal minimally invasive surgery (TAMIS). A case-control matched-pairs analysis demonstrated that these modalities to perform LE resulted in similar results $[85,86]$. The main advantages of LE (compared to RS) are the lower risk of postoperative morbidity $[87,88]$ and the avoidance of colostomy in a significant percentage of patients with low-RC.

\section{Patients with early RC}

LE was initially recommended in patients with cTis/ T1N0M0 mid/low-RC. Theoretical assumption that supports this approach is the low risk of lymph node metastases or disseminated disease in such patients. By this reason, it was considered that for these patients TME might be unnecessary, as long as LE of primary tumor with a $1 \mathrm{~cm}$ safety margin could entirely remove primary tumor without jeopardizing long-term oncological outcomes [26, 86, 89].

A retrospective analysis of more than 10000 patients with T1 RC included in NCDB between 2008 and 2016 revealed a significant increase in the use of LE approach over the time (from $52.69 \%$ in 2008 to $69.47 \%$ in 2016, $p<0.001$ ) [86]. Moreover, the 5-year OS rates were not significantly different in patients who underwent LE compared to those treated by RS $(82.65 \%$ vs. $83.53 \%$, respectively; $p=0.639$ ) [86]. Even earlier studies suggested that LE achieved OS and DFS rates similar to those accomplished by RS [90-93]. However, LRRs tended to be higher in T1N0M0 patients treated by LE than in those who underwent RS $[90,93,94]$. To better select patients for LE, some investigators evaluated the predictors for higher LRR and lower survival outcomes. The main reason for local or distant recurrence in patients with $\mathrm{pT} 1$ $\mathrm{RC}$ treated by LE with safety margin is the presence of metastatic LNs. A meta-analysis of 3621 patients with pT1 RC revealed that the independent predictors for LN metastases were lympho-vascular invasion, tumor invasion into submucosa deeper than $1 \mathrm{~mm}$, tumor budding and poor histological differentiation [95]. The depth of submucosal invasion by $\mathrm{RC}$ was divided in three degrees: $\mathrm{Sm} 1-$ invasion of the upper third of submucosa, $\mathrm{Sm} 2$ - invasion in the middle third and Sm3 - invasion of the lower third. Morino et al. revealed that recurrence rate after LE was 0\% in $\mathrm{Sm} 1$ and $22.7 \%$ in $\mathrm{Sm} 2$ or $\mathrm{Sm} 3$ [96]. If pathological evaluation of the resected specimen after LE reveal the presence of such high-risk factors, or incomplete resection margins (R1/R2), immediate RS should be recommended due to the high-risk of recurrence. The oncological outcomes achieved by RS after LE in patients with high-risk pathological factors seems to be similar to those of patients treated with up-front RS [97, 98]. Elderly or high surgical risk patients, as well as those who refuse RS might benefit from adjuvant (chemo)radiotherapy [26].

However, in pT2 patients who underwent LE, even the addition of adjuvant CRT was associated with significantly 
lower survival rates than to those achieved by LE alone in patients with pT1 RC. Thus, Greenberg et al. revealed that 10 -year OS and DFS were $84 \%$ and $75 \%$ for pT1 patients treated with LE, and $66 \%$ and $64 \%$ for pT2 patients treated with LE followed by adjuvant CRT [99]. Moreover, local and distant recurrence rates for $\mathrm{pT} 1$ tumors were $8 \%$ and $5 \%$, while in pT2 patients were $18 \%$ and $12 \%$ even after adjuvant CRT [99].

A recent randomized study (TREC) evaluated the potential role of LE after neoadjuvant short-course RT in patients with early RC (T1-2N0M0) [100]. TREC study assessed the feasibility of randomly assigning eligible patients with early-stage RC to either RS without preoperative RT, or LE after neoadjuvant short-course RT [100]. The study also contained a non-randomized registry including patients for whom randomization was considered inappropriate, due to a strong clinical indication for one of the treatment options (e.g., elderly/frail patients with many comorbidities that were considered unsuitable for RS underwent RT and subsequent LE) [100]. The pCR was observed in $30 \%$ of patients randomized to neoadjuvant RT followed by LE and in $41 \%$ of non-randomized patients who underwent neoadjuvant RT and LE [100]. An intentionto-treat analysis revealed, in randomized patients, that incidence of serious adverse events was significantly lower in LE group compared to those in RS group (15\% vs. $39 \%$, respectively, $p=0.04)$. Moreover, patient-reported quality of life (QoL) and function scores were improved in the group of patients randomly assigned to LE than in RS group [100]. Although TREC study has not been designated to compare the long-term outcomes achieved by the two therapeutic strategies, survival analysis revealed that although patients randomly assigned to RT followed by LE had lower OS and DFS rates compared to those assigned to $\mathrm{RS}$, the differences were not statistically significant [100]. However, only 19 out of $27(70 \%)$ patients randomly assigned to LE achieved organ preservation, the other eight $(30 \%)$ patients undergoing RS (early-per protocol conversion in five patients and TEM difficulties in three patients) [100]. Due to the favorable short-term and functional outcomes achieved by rectum-sparing approach, TREC study supports further evaluation of short-term RT followed by LE in patients with early RC in the context of larger randomized clinical trials aiming to investigate the long-term outcomes of this organ-preserving approach.

\section{Patients with LARC (cT3-4N0-2MO)}

In patients with more advanced tumors (cT3-4N02M0) that achieved cCR after neoadjuvant CRT, LE was recommended (by most authors) only when important co-morbidities were present (such as obesity, or high-risk cardiovascular, pulmonary or neurological disease) and abdominoperineal resection or coloanal anastomosis with intersphincteric resection were required [101]. However, in patients with ypT2-4 and/or R1 resection and/or lymphovascular invasion (on pathological examination of LE specimen) a salvage RS was recommended following LE, in most studies [101-104].

In the last decade, prospective trials have been undertaken to evaluate feasibility and outcomes of LE in patients with LARC who experienced cCR after neoadjuvant CRT. In most of these trials, ypT2-4 stage or R1 resection represented indications for immediate RS.
A phase 2 feasibility trial (CARTS study) reported that almost two thirds of patients with T1-3N0M0 RC enabled organ preservation with LE after neoadjuvant CRT [105]. In GRE3CCAR2 trial (a phase 3 randomized clinical trial), patients with cT2-3N0-1M0 stage at baseline received neoadjuvant CRT; those patients who achieved a good response after CRT (consisting in a smaller than $2 \mathrm{~cm}$ scar at DRE and rectoscopy) were randomly assigned to LE or RS. Patients assigned to LE who had ypT2-3 or R1 on pathological examination specimen were referred to completion TME (RS). All the patients were followed at four months for the next five years after surgery, and those who relapsed were treated according to the current clinical guidelines. By using this approach, per-protocol analysis revealed that 43 out of 81 (53\%) patients eventually achieved organ preservation [106]. The study aimed to evaluate the potential superiority of LE over RS in good responders after neoadjuvant CRT, especially in terms of short-term outcomes, LR and side-effects (e.g., colostomy, fecal incontinence or sexual dysfunction) [106]. Such superior outcomes have been suggested by earlier retrospective studies.

Thus, a case-matched study compared the outcomes of LE and RS in patients who achieved cCR after neoadjuvant CRT. Overall morbidity rate was significantly higher following RS (65\%) than after LE (26\%), although there was no significant difference between major morbidity rates in LE group vs RS group (3\% vs. 4\%, respectively) [101]. GRECCAR2 trial revealed that almost $46 \%$ of patients randomly assigned to LE after neoadjuvant CRT needed completion RS, which was associated with significantly higher rates of overall and major morbidity $(78 \%$ and $46 \%$, respectively), compared to LE (29\% and $12 \%$, respectively) or initial RS ( $38 \%$ and $22 \%$, respectively) $(p<0.01)$ [106]. By this reason, GRECCAR2 trial failed to demonstrate in an intention-to-treat analysis, as well as in per protocol analysis, that LE is associated with significantly lower morbidity rates compared to RS [106].

However, the strategy employed in GRECCAR2 trial seems to be oncologically safe, as long as in an intentionto-treat analysis the three-year DFS and OS rates achieved by LE $(78.3 \%$ and $91.9 \%$, respectively) and RS (76.1\% and $91.5 \%$, respectively) were not significantly different ( $p=0.45$ and $p=0.92$ for DFS and OS, respectively). Similarly, a per-protocol analysis found similar three-year LRRs after LE or RS ( $6 \%$ vs. 3\%, respectively; $p=0.63$ ) [106]. These results are in line with long-term outcomes reported in the literature for LE in patients who achieved cCR after neoadjuvant CRT. Calmels et al. showed similar oncological outcomes in the LE group and RS group: LRRs were 5\% and $3 \%$, respectively $(p=0.601)$ and distant recurrence rates were $8 \%$ and $7 \%$, respectively $(p=1)$ [101]. Likewise, a prospective (CARTS) study reported that LE enabled a five-year LRR of $7.7 \%$, as well as five-year DFS and OS rates of $81.6 \%$ and $82.8 \%$, respectively [105].

Moreover, CARTS study reported better QoL in patients treated by LE, with improved emotional well-being during follow-up, compared to those managed by RS [105]. Also, a recent retrospective study revealed that patients who underwent a rectum-sparing approach (LE or WW) had better intestinal $(p<0.01)$, sexual $(p=0.04)$ functional and emotional status ( $p=0.02)$ compared to RS patients [107]. 
So far, most guidelines recommend LE only in cTisT1 patients with low-risk pathological features [108]. In patients who achieved a cCR after neoadjuvant CRT, most guidelines still endorse RS as "gold standard" treatment [108]. European Society for Medical Oncology (ESMO), Italian and Netherlands Guidelines recommend LE of the tumor bed (after cCR), but aware about the need for thorough pathological evaluation [108]. In case of ypT2-3, patients should immediately undergo RS. European Association for Endoscopic Surgery (EAES) and French Guidelines proposed LE only within the setting of clinical trials [108]. In patients with high-risk pathological features on the specimen of LE (ypT2-3, R1, lympho-vascular invasion), current guidelines recommend immediate RS, unless the patients refuse or poor performance status [26]. In patients without cCR or having $\mathrm{cN1} 1-2$ stage, RS is mandatory. For such patients, small retrospective low-quality studies evaluated the results of LE, reporting LRR ranging between $4 \%$ and $15 \%$, three-year DFS rates up to $90 \%$ [109-111].

\section{Watch and wait}

The better functional results and improved QoL achieved by LE were the main reasons for exploring the safety and efficacy of non-operative management in patients who achieved cCR after neoadjuvant CRT. A Brazilian group led by Angelita Habr-Gama pioneered the WW approach, consisting in close follow-up of patients who achieved cCR after neoadjuvant CRT [8]. In the seminal study published in 2004, the authors compared the long-term outcomes achieved by WW approach in 71 patients who had cCR after neoadjuvant CRT to those of 22 patients with pCR observed on the specimen of RS. After more than 48 months follow-up, there have been two LRs in WW group and three distant recurrences in each group $(p=0.02)$. Although five-year DFS rates were not statistical significantly different between WW and RS group ( $92 \%$ vs. 83\%, respectively; $p=0.09)$, the five-year OS rate enabled by WW was significantly higher than those achieved by RS (100\% vs. 88\%, respectively; $p=0.01$ ) [8]. In an updated evaluation, Habr-Gama et al. reported after a mean followup of almost five years a LRR of 5\%, a distant metastases rate of $7.1 \%$ and a combined local and distal recurrence of $1 \%$ [112]. Small sample size studies suggested that WW approach is able to achieve long-term oncological outcomes similar to those observed after RS in patients with cCR [113]. However, larger retrospective studies and meta-analysis reported different results. A recent analysis of 880 patients with cCR after neoadjuvant CRT (enrolled in the $W W$ International Registry) revealed a two-year local re-growth rate of $25.3 \%$, with $77.6 \%$ of the recurrences treated by RS and the others by LE [114]. The five-year OS and DSS rates were $84.6 \%$ and $93.8 \%$, respectively, for the entire group and $75.4 \%$ and $84 \%$, respectively, in patients who developed local re-growth [114]. A metaanalysis of nine studies compared the long-term outcomes achieved by WW (348 patients) and RS (453 patients) [115] revealing that WW approach achieved two-year LRRs and five-year DFS rates similar to those observed in patients treated by RS, irrespective their pathological staging. Furthermore, five-year OS rate accomplished by WW was significantly higher than those achieved by RS in all the patients $(p=0.046)$ [115]. However, compared to patients with pCR proved by pathological examinations of the RS specimen, the two-year LRR was significantly higher in WW group, while five-year DFS and OS rates were significantly lower in WW group [115]. Based on this evidence, caution is recommended before offering this approach, whose application should be limited in present only to elderly, fragile (high-risk) patients or those refusing RS [26, 34, 116].

Nonetheless, when WW approach is chosen, close follow-up is mandatory, especially during the first three years, because local regrowth and distant metastases usually occur in this time interval after the end of CRT. A recent multicentric study showed that the probability of remaining free from local regrowth for an additional two years if a patient had a sustained cCR for three years was $97.3 \%$ and the probability of remaining free from distant metastasis for a further two years in patients without distant metastasis at three years was $97.8 \%$ [117]. A recent consensus recommended an intensified follow-up regimen in the first three years after CRT, consisting in serum carcinoembryonic antigen (CEA) evaluation every three months, DRE, rectoscopy and pelvic MRI every 3-4 months as well as chest and abdominal CT scan at six months. Since the fourth year after CRT, the follow-up regimen could be de-intensified, consisting in serum CEA evaluation, DRE, rectoscopy and pelvic MRI every six months and chest and abdominal CT scan at 12 months [40].

\section{a Conclusions}

Patients with cTis-T1N0 M0 could be safely and efficiently treated by LE, avoiding RS. In more advanced $\mathrm{RC}$, neoadjuvant CRT followed by RS is still the "gold standard" approach. However, pCR after neoadjuvant CRT could be achieve in up to $30 \%$ patients, depending mainly on the initial cT stage, tumor volume at baseline, type of neoadjuvant CRT, as well as pathological and molecular features of the tumor. In such patients, the oncological outcomes are better than those observed in patients without pCR. Moreover, in patients with pCR, LE enables potentially better short-term outcomes and QoL, compared to RS. Furthermore, long-term outcomes achieved by LE seems to be similar to those of RS in patients with pCR or lowrisk ypT1. Unfortunately, evaluation of $\mathrm{pCR}$ is challenging, because cCR does not translate in pCR in all the patients. By this reason, the accurate evaluation of response to neoadjuvant CRT has paramount importance and the achievement of cCR should be estimated based on DRE, rectoscopy and novel imaging methods (especially MRI features). Caution should be recommended before the application of a watch and wait policy in patients with cCR. This approach is recommended in present only in elderly, high-risk patients, with limited estimated lifeexpectancy. For patients fit for RS, WW approach should be employed in the setting of clinical trials or in case of patients' refusal of RS.

\section{Conflict of interests}

The authors declare that they have no conflict of interests.

\section{Authors' contribution}

The authors contributed to the documentation process, conceptualization of the article, writing and corrections and they approved the final version sent to the Editor. 


\section{References}

[1] Heald RJ, Husband EM, Ryall RDH. The mesorectum in rectal cancer surgery - the clue to pelvic recurrence? Br J Surg, 1982, 69(10):613-616. https://doi.org/10.1002/bjs.18006910 19 PMID: 6751457

[2] Anderson JM. Chemoradiotherapeutic prevention of local recurrence after stapled anastomoses in rectal cancer. Scott Med J, 1981, 26(1):21-23. https://doi.org/10.1177/00369330 8102600106 PMID: 6791280

[3] Heald RJ, Moran BJ, Ryall RDH, Sexton R, MacFarlane JK. Rectal cancer: the Basingstoke experience of total mesorectal excision, 1978-1997. Arch Surg, 1998, 133(8):894-899. https:// doi.org/10.1001/archsurg.133.8.894 PMID: 9711965

[4] Vauthey JN, Marsh RW, Zlotecki RA, Abdalla EK, Solorzano CC, Bray EJ, Freeman ME, Lauwers GY, Kubilis PS, Mendenhall WM, Copeland EM 3rd. Recent advances in the treatment and outcome of locally advanced rectal cancer. Ann Surg, 1999, 229(5):745-752; discussion 752-754. https://doi.org/10.1097/ 00000658-199905000-00018 PMID: 10235534 PMCID: PMC 1420820

[5] Peng HH, Liao ZW, Lin XD, Qiu XS, You KY. Definitive radiotherapy or chemoradiotherapy for distal rectal cancer with early stage of cT1-2N0. Cancer Manag Res, 2019, 11:52215229. https://doi.org/10.2147/CMAR.S198113 PMID: 31354342 PMCID: PMC6578584

[6] Hasan S, Renz P, Wegner RE, Finley G, Raj M, Monga D, McCormick J, Kirichenko A. Microsatellite instability (MSI) as an independent predictor of pathologic complete response (PCR) in locally advanced rectal cancer: a National Cancer Database (NCDB) analysis. Ann Surg, 2020, 271(4):716-723 https://doi.org/10.1097/SLA.0000000000003051 PMID: 30216221 PMCID: PMC7418064

[7] Al-Sukhni E, Attwood K, Mattson DM, Gabriel E, Nurkin SJ. Predictors of pathologic complete response following neoadjuvant chemoradiotherapy for rectal cancer. Ann Surg Oncol, 2016, 23(4):1177-1186. https://doi.org/10.1245/s10434-015-5017-y PMID: 26668083 PMCID: PMC5295136

[8] Habr-Gama A, Perez RO, Nadalin W, Sabbaga J, Ribeiro U Jr, Silva e Sousa AH Jr, Campos FG, Kiss DR, Gama-Rodrigues J. Operative versus nonoperative treatment for stage 0 distal rectal cancer following chemoradiation therapy: long-term results. Ann Surg, 2004, 240(4):711-717; discussion 717-718. https:// doi.org/10.1097/01.sla.0000141194.27992.32 PMID: 15383798 PMCID: PMC1356472

[9] Maas M, Nelemans PJ, Valentini V, Das P, Rödel C, Kuo LJ, Calvo FA, García-Aguilar J, Glynne-Jones R, Haustermans K, Mohiuddin M, Pucciarelli S, Small W Jr, Suárez J, Theodoropoulos G, Biondo S, Beets-Tan RG, Beets GL. Long-term outcome in patients with a pathological complete response after chemoradiation for rectal cancer: a pooled analysis of individual patient data. Lancet Oncol, 2010, 11(9):835-844. https://doi.org/10.1016/S1470-2045(10)70172-8 PMID: 20692872

[10] Påhlman L, Bohe M, Cedermark B, Dahlberg M, Lindmark G, Sjödahl R, Ojerskog B, Damber L, Johansson R. The Swedish Rectal Cancer Registry. Br J Surg, 2007, 94(10):1285-1292. https://doi.org/10.1002/bjs.5679 PMID: 17661309

[11] Dalton RSJ, Velineni R, Osborne ME, Thomas R, Harries S, Gee AS, Daniels IR. A single-centre experience of chemoradiotherapy for rectal cancer: is there potential for nonoperative management? Colorectal Dis, 2012, 14(5):567-571. https:// doi.org/10.1111/j.1463-1318.2011.02752.x PMID: 21831177

[12] Sinukumar S, Patil P, Engineer R, Desouza A, Saklani A. Clinical outcome of patients with complete pathological response to neoadjuvant chemoradiotherapy for locally advanced rectal cancers: the Indian scenario. Gastroenterol Res Pract, 2014 2014:867841. https://doi.org/10.1155/2014/867841 PMID: 25610460 PMCID: PMC4295335

[13] Martoni AA, Di Fabio F, Pinto C, Castellucci P, Pini S, Ceccarelli C, Cuicchi D, lacopino B, Di Tullio P, Giaquinta S, Tardio L, Lombardi R, Fanti S, Cola B. Prospective study on the FDG-PET/CT predictive and prognostic values in patients treated with neoadjuvant chemoradiation therapy and radical surgery for locally advanced rectal cancer. Ann Oncol, 2011, 22(3):650-656. https://doi.org/10.1093/annonc/mdq433 PMID: 20847032

[14] Dworak O, Keilholz L, Hoffmann A. Pathological features of rectal cancer after preoperative radiochemotherapy. Int $\mathrm{J}$
Colorectal Dis, 1997, 12(1):19-23. https://doi.org/10.1007/s00 3840050072 PMID: 9112145

[15] Baek JH, Baek DW, Kang BW, Kim HJ, Park SY, Park JS, Choi GS, Kim JG. Prognostic impact of the neoadjuvant rectal score as compared with the tumor regression grade and yield pathologic TNM stage in patients with locally advanced rectal cancer after neoadjuvant chemoradiotherapy. In Vivo, 2020, 34(4):1993-1999. https://doi.org/10.21873/invivo.11997 PMID: 32606172 PMCID: PMC7439879

[16] Japanese Society for Cancer of the Colon and Rectum. Japanese Classification of Colorectal, Appendiceal, and Anal Carcinoma: the 3d English Edition [Secondary Publication]. J Anus Rectum Colon, 2019, 3(4):175-195. https://doi.org/ 10.23922/jarc.2019-018 PMID: 31768468 PMCID: PMC6845287

[17] Díaz-González JA, Calvo FA, Cortés J, García-Sabrido JL, Gómez-Espí M, Del Valle E, Muñoz-Jiménez F, Alvarez E. Prognostic factors for disease-free survival in patients with T3-4 or N+ rectal cancer treated with preoperative chemoradiation therapy, surgery, and intraoperative irradiation. Int $\mathrm{J}$ Radiat Oncol Biol Phys, 2006, 64(4):1122-1128. https://doi. org/10.1016/j.ijrobp.2005.09.020 PMID: 16406393

[18] Sauer R, Becker H, Hohenberger W, Rödel C, Wittekind C, Fietkau R, Martus P, Tschmelitsch J, Hager E, Hess CF. Karstens JH, Liersch T, Schmidberger H, Raab R; German Rectal Cancer Study Group. Preoperative versus postoperative chemoradiotherapy for rectal cancer. N Engl J Med, 2004, 351(17):1731-1740. https://doi.org/10.1056/NEJMoa040694 PMID: 15496622

[19] Shivnani AT, Small W Jr, Stryker SJ, Kiel KD, Lim S, Halverson AL, Talamonti MS. Preoperative chemoradiation for rectal cancer: results of multimodality management and analysis of prognostic factors. Am J Surg, 2007, 193(3):389393; discussion 393-394. https://doi.org/10.1016/j.amjsurg. 2006.09.030 PMID: 17320541

[20] Sorenson E, Lambreton F, Yu JQ, Li T, Denlinger CS, Meyer JE, Sigurdson ER, Farma JM. Impact of PET/CT for restaging patients with locally advanced rectal cancer after neoadjuvant chemoradiation. J Surg Res, 2019, 243:242-248. https://doi. org/10.1016/j.jss.2019.04.080 PMID: 31229791 PMCID: PMC 7751164

[21] Guillem JG, Ruby JA, Leibold T, Akhurst TJ, Yeung HW Gollub MJ, Ginsberg MS, Shia J, Suriawinata AA, Riedel ER, Mazumdar M, Saltz LB, Minsky BD, Nash GM, Paty PB, Temple LK, Weiser MR, Larson SM. Neither FDG-PET nor CT can distinguish between a pathological complete response and an incomplete response after neoadjuvant chemoradiation in locally advanced rectal cancer: a prospective study. Ann Surg, 2013, 258(2):289-295. https://doi.org/10.1097/SLA.0b 013e318277b625 PMID: 23187748

[22] Maas M, Beets-Tan RGH, Lambregts DMJ, Lammering G, Nelemans PJ, Engelen SME, van Dam RM, Jansen RLH, Sosef M, Leijtens JWA, Hulsewé KWE, Buijsen J, Beets GL. Wait-and-see policy for clinical complete responders after chemoradiation for rectal cancer. J Clin Oncol, 2011, 29(35): 4633-4640. https://doi.org/10.1200/JCO.2011.37.7176 PMID: 22067400

[23] Habr-Gama A, Perez RO, Wynn G, Marks J, Kessler H, GamaRodrigues J. Complete clinical response after neoadjuvant chemoradiation therapy for distal rectal cancer: characterization of clinical and endoscopic findings for standardization. Dis Colon Rectum, 2010, 53(12):1692-1698. https://doi.org/10.1007/DCR. Ob013e3181f42b89 PMID: 21178866

[24] Li J, Liu H, Yin J, Liu S, Hu J, Du F, Yuan J, Lv B, Fan J, Leng $S$, Zhang $X$. Wait-and-see or radical surgery for rectal cancer patients with a clinical complete response after neoadjuvant chemoradiotherapy: a cohort study. Oncotarget, 2015, 6(39):42354-42361. https://doi.org/10.18632/oncotarget. 6093 PMID: 26472284 PMCID: PMC4747231

[25] Smith JD, Ruby JA, Goodman KA, Saltz LB, Guillem JG, Weiser MR, Temple LK, Nash GM, Paty PB. Nonoperative management of rectal cancer with complete clinical response after neoadjuvant therapy. Ann Surg, 2012, 256(6):965-972. https://doi.org/10.1097/SLA.0b013e3182759f1c PMID: 23154394

[26] Glynne-Jones R, Wyrwicz L, Tiret E, Brown G, Rödel C Cervantes A, Arnold D; ESMO Guidelines Committee. Rectal cancer: ESMO Clinical Practice Guidelines for diagnosis, treatment and follow-up. Ann Oncol, 2017, 28(Suppl 4):iv22iv40. https://doi.org/10.1093/annonc/mdx224 PMID: 28881920 
[27] Lai CL, Lai MJ, Wu CC, Jao SW, Hsiao CW. Rectal cancer with complete clinical response after neoadjuvant chemoradiotherapy, surgery, or "watch and wait". Int J Colorectal Dis, 2016, 31(2): 413-419. https://doi.org/10.1007/s00384-015-2460-y PMID: 26607907

[28] Habr-Gama A. Assessment and management of the complete clinical response of rectal cancer to chemoradiotherapy. Colorectal Dis, 2006, 8(Suppl 3):21-24. https://doi.org/10. 1111/j.1463-1318.2006.01066.x PMID: 16813588

[29] Maggiori L, Bretagnol F, Aslam MI, Guedj N, Zappa M, Ferron M, Panis Y. Does pathologic response of rectal cancer influence postoperative morbidity after neoadjuvant radiochemotherapy and total mesorectal excision? Surgery, 2014, 155(3):468-475. https://doi.org/10.1016/j.surg.2013.10.020 PMID: 24439750

[30] Guillem JG, Chessin DB, Shia J, Moore HG, Mazumdar M, Bernard B, Paty PB, Saltz L, Minsky BD, Weiser MR, Temple LKF, Cohen AM, Wong WD. Clinical examination following preoperative chemoradiation for rectal cancer is not a reliable surrogate end point. J Clin Oncol, 2005, 23(15):3475-3479. https://doi.org/ 10.1200/JCO.2005.06.114 PMID: 15908656

[31] Hughes R, Harrison M, Glynne-Jones R. Could a wait and see policy be justified in T3/4 rectal cancers after chemoradiotherapy? Acta Oncol, 2010, 49(3):378-381. https://doi. org/10.3109/02841860903483692 PMID: 20151936

[32] Garcia-Aguilar J, Shi Q, Thomas CR Jr, Chan E, Cataldo P, Marcet J, Medich D, Pigazzi A, Oommen S, Posner MC A phase II trial of neoadjuvant chemoradiation and local excision for T2NO rectal cancer: preliminary results of the ACOSOG Z6041 trial. Ann Surg Oncol, 2012, 19(2):384-391. https://doi.org/10.1245/s10434-011-1933-7 PMID: 21755378 PMCID: PMC5720824

[33] Smith FM, Wiland H, Mace A, Pai RK, Kalady MF. Clinical criteria underestimate complete pathological response in rectal cancer treated with neoadjuvant chemoradiotherapy. Dis Colon Rectum, 2014, 57(3):311-315. https://doi.org/10.1097/DCR. Ob013e3182a84eba PMID: 24509452

[34] Kuo LJ, Chiou JF, Tai CJ, Chang CC, Kung CH, Lin SE, Hung CS, Wang W, Tam KW, Lee HC, Liang HH, Chang YJ, Wei PL. Can we predict pathologic complete response before surgery for locally advanced rectal cancer treated with preoperative chemoradiation therapy? Int J Colorectal Dis, 2012, 27(5): 613-621. https://doi.org/10.1007/s00384-011-1348-8 PMID: 22080392

[35] Perez RO, Habr-Gama A, Pereira GV, Lynn PB, Alves PA Proscurshim I, Rawet V, Gama-Rodrigues J. Role of biopsies in patients with residual rectal cancer following neoadjuvant chemoradiation after downsizing: can they rule out persisting cancer? Colorectal Dis, 2012, 14(6):714-720. https://doi.org/ 10.1111/j.1463-1318.2011.02761.x PMID: 22568644

[36] Hayden DM, Jakate S, Pinzon MCM, Giusto D, Francescatti AB Brand MI, Saclarides TJ. Tumor scatter after neoadjuvant therapy for rectal cancer: are we dealing with an invisible margin? Dis Colon Rectum, 2012, 55(12):1206-1212. https:// doi.org/10.1097/DCR.0b013e318269fdb3 PMID: 23135577

[37] Duldulao MP, Lee W, Streja L, Chu P, Li W, Chen Z, Kim J, Garcia-Aguilar J. Distribution of residual cancer cells in the bowel wall after neoadjuvant chemoradiation in patients with rectal cancer. Dis Colon Rectum, 2013, 56(2):142-149. https:// doi.org/10.1097/DCR.0b013e31827541e2 PMID: 23303141 PMCID: PMC4674069

[38] Martens MH, Maas M, Heijnen LA, Lambregts DMJ, Leijtens JWA Stassen LPS, Breukink SO, Hoff C, Belgers EJ, Melenhorst J, Jansen R, Buijsen J, Hoofwijk TGM, Beets-Tan RGH, Beets GL. Long-term outcome of an organ preservation program after neoadjuvant treatment for rectal cancer. J Natl Cancer Inst 2016, 108(12):djw171. https://doi.org/10.1093/jnci/djw171 PMID: 27509881

[39] Maas M, Lambregts DMJ, Nelemans PJ, Heijnen LA, Martens MH, Leijtens JWA, Sosef M, Hulsewé KWE, Hoff C, Breukink SO, Stassen L, Beets-Tan RGH, Beets GL. Assessment of clinical complete response after chemoradiation for rectal cancer with digital rectal examination, endoscopy, and MRI: selection for organ-saving treatment. Ann Surg Oncol, 2015, 22(12): 3873-3880. https://doi.org/10.1245/s10434-015-4687-9 PMID: 26198074 PMCID: PMC4595525

[40] Fokas E, Appelt A, Glynne-Jones R, Beets G, Perez R, GarciaAguilar J, Rullier E, Joshua Smith J, Marijnen C, Peters FP, van der Valk M, Beets-Tan R, Myint AS, Gerard JP, Bach SP, Ghadimi M, Hofheinz RD, Bujko K, Gani C, Haustermans K, Minsky BD, Ludmir E, West NP, Gambacorta MA, Valentini V, Buyse M, Renehan AG, Gilbert A, Sebag-Montefiore D, Rödel C. International consensus recommendations on key outcome measures for organ preservation after (chemo)radiotherapy in patients with rectal cancer. Nat Rev Clin Oncol, 2021, 18(12):805-816. https://doi.org/10.1038/s41571-021-00538-5 PMID: 34349247

[41] Beets GL, Figueiredo NF, Beets-Tan RGH. Management of rectal cancer without radical resection. Annu Rev Med, 2017, 68:169-182. https://doi.org/10.1146/annurev-med-062915-02 1419 PMID: 27618750

[42] Sun W, Al-Rajabi R, Perez RO, Abbasi S, Ash R, Habr-Gama A. Controversies in rectal cancer treatment and management. Am Soc Clin Oncol Educ Book, 2020, 40:1-11. https://doi.org/ 10.1200/EDBK 279871 PMID: 32239978

[43] Horvat N, Veeraraghavan H, Khan M, Blazic I, Zheng J, Capanu M, Sala E, Garcia-Aguilar J, Gollub MJ, Petkovska I. MR imaging of rectal cancer: radiomics analysis to assess treatment response after neoadjuvant therapy. Radiology, 2018, 287(3):833-843. https://doi.org/10.1148/radiol.201817 2300 PMID: 29514017 PMCID: PMC5978457

[44] Patel UB, Brown G, Rutten H, West N, Sebag-Montefiore D, Glynne-Jones R, Rullier E, Peeters M, Van Cutsem E, Ricci S, Van de Velde C, Kjell P, Quirke P. Comparison of magnetic resonance imaging and histopathological response to chemoradiotherapy in locally advanced rectal cancer. Ann Surg Oncol, 2012, 19(9):2842-2852. https://doi.org/10.1245/s10434-0122309-3 PMID: 22526897

[45] Lubner MG, Stabo N, Abel EJ, Del Rio AM, Pickhardt PJ. CT textural analysis of large primary renal cell carcinomas: pretreatment tumor heterogeneity correlates with histologic findings and clinical outcomes. AJR Am J Roentgenol, 2016, 207(1):96-105. https://doi.org/10.2214/AJR.15.15451 PMID: 27145377

[46] Gillies RJ, Kinahan PE, Hricak H. Radiomics: images are more than pictures, they are data. Radiology, 2016, 278(2): 563-577. https://doi.org/10.1148/radiol.2015151169 PMID: 26579733 PMCID: PMC4734157

[47] Jayaprakasam VS, Paroder V, Gibbs P, Bajwa R, Gangai N, Sosa RE, Petkovska I, Golia Pernicka JS, Fuqua JL 3rd, Bates DDB, Weiser MR, Cercek A, Gollub MJ. MRI radiomics features of mesorectal fat can predict response to neoadjuvant chemoradiation therapy and tumor recurrence in patients with locally advanced rectal cancer. Eur Radiol, 2021, Jul 29. https:// doi.org/10.1007/s00330-021-08144-w PMID: 34327580

[48] Shaish H, Aukerman A, Vanguri R, Spinelli A, Armenta P, Jambawalikar S, Makkar J, Bentley-Hibbert S, Del Portillo A, Kiran R, Monti L, Bonifacio C, Kirienko M, Gardner KL, Schwartz L, Keller D. Radiomics of MRI for pretreatment prediction of pathologic complete response, tumor regression grade, and neoadjuvant rectal score in patients with locally advanced rectal cancer undergoing neoadjuvant chemoradiation: an international multicenter study. Eur Radiol, 2020, 30(11): 6263-6273. https://doi.org/10.1007/s00330-020-06968-6 PMID: 32500192

[49] Calvo FA, Domper M, Matute R, Martínez-Lázaro R, Arranz JA Desco M, Alvarez E, Carreras JL. ${ }^{18} \mathrm{~F}-\mathrm{FDG}$ positron emission tomography staging and restaging in rectal cancer treated with preoperative chemoradiation. Int J Radiat Oncol Biol Phys, 2004, 58(2):528-535. https://doi.org/10.1016/j.jijobp.2003.09. 058 PMID: 14751524

[50] Capirci C, Rampin L, Erba PA, Galeotti F, Crepaldi G, Banti E, Gava M, Fanti S, Mariani G, Muzzio PC, Rubello D. Sequential FDG-PET/CT reliably predicts response of locally advanced rectal cancer to neo-adjuvant chemo-radiation therapy. Eur $\mathrm{J}$ Nucl Med Mol Imaging, 2007, 34(10):1583-1593. https://doi. org/10.1007/s00259-007-0426-1 PMID: 17503039

[51] Vliegen RFA, Beets-Tan RG, Vanhauten B, Driessen A, Oellers M, Kessels AG, Arens A, Beets GL, Buijsen J, van Baardwijk A, de Ruysscher D, Lammering G. Can an FDG$\mathrm{PET} / \mathrm{CT}$ predict tumor clearance of the mesorectal fascia after preoperative chemoradiation of locally advanced rectal cancer? Strahlenther Onkol, 2008, 184(9):457-464. https:// doi.org/10.1007/s00066-008-1858-7 PMID: 19016024

[52] Chen Z, Duldulao MP, Li W, Lee W, Kim J, Garcia-Aguilar J. Molecular diagnosis of response to neoadjuvant chemoradiation 
therapy in patients with locally advanced rectal cancer. J Am Coll Surg, 2011, 212(6):1008-1017.e1. https://doi.org/10.1016/ j.jamcollsurg.2011.02.024 PMID: 21458303 PMCID: PMC 3104075

[53] Dossa F, Chesney TR, Acuna SA, Baxter NN. A watch-andwait approach for locally advanced rectal cancer after a clinica complete response following neoadjuvant chemoradiation: a systematic review and meta-analysis. Lancet Gastroenterol Hepatol, 2017, 2(7):501-513. https://doi.org/10.1016/S24681253(17)30074-2 PMID: 28479372

[54] Das P, Skibber JM, Rodriguez-Bigas MA, Feig BW, Chang GJ, Wolff RA, Eng C, Krishnan S, Janjan NA, Crane CH. Predictors of tumor response and downstaging in patients who receive preoperative chemoradiation for rectal cancer. Cancer, 2007, 109(9):1750-1755. https://doi.org/10.1002/cncr.22625 PMID: 17387743

[55] Rijkmans EC, Marijnen CAM, van Triest B, Ketelaars M, Cats A, Inderson A, van den Ende RPJ, Laman MS, Kerkhof EM, Nout RA. Predictive factors for response and toxicity after brachytherapy for rectal cancer; results from the HERBERT study. Radiother Oncol, 2019, 133:176-182. https://doi.org/ 10.1016/j.radonc.2019.01.034 PMID: 30935576

[56] van Stiphout RGPM, Valentini V, Buijsen J, Lammering G, Meldolesi E, van Soest J, Leccisotti L, Giordano A, Gambacorta MA, Dekker A, Lambin P. Nomogram predicting response after chemoradiotherapy in rectal cancer using sequentia PETCT imaging: a multicentric prospective study with external validation. Radiother Oncol, 2014, 113(2):215-222. https:// doi.org/10.1016/j.radonc.2014.11.002 PMID: 25466368

[57] Dubben HH, Thames HD, Beck-Bornholdt HP. Tumor volume: a basic and specific response predictor in radiotherapy. Radiother Oncol, 1998, 47(2):167-174. https://doi.org/10.1016/s01678140(97)00215-6 PMID: 9683365

[58] Bentzen SM, Thames HD. Tumor volume and local contro probability: clinical data and radiobiological interpretations. Int J Radiat Oncol Biol Phys, 1996, 36(1):247-251. https:// doi.org/10.1016/s0360-3016(96)00242-8 PMID: 8823282

[59] Lutsyk M, Awawda M, Gourevich K, Ben Yosef R. Tumor volume as predictor of pathologic complete response following neoadjuvant chemoradiation in locally advanced rectal cancer. Am J Clin Oncol, 2021, 44(9):482-486. https://doi.org/10.1097/ COC.0000000000000846 PMID: 34269693

[60] van Stiphout RGPM, Lammering G, Buijsen J, Janssen MHM, Gambacorta MA, Slagmolen P, Lambrecht M, Rubello D, Gava M, Giordano A, Postma EO, Haustermans K, Capirci C, Valentini V, Lambin P. Development and external validation of a predictive model for pathological complete response of rectal cancer patients including sequential PET-CT imaging. Radiother Oncol, 2011, 98(1):126-133. https://doi.org/10.1016/ j.radonc.2010.12.002 PMID: 21176986

[61] Zhang J, Xie X, Wu Z, Hu H, Cai Y, Li J, Ling J, Ding M, Li W, Deng $Y$. Mucinous adenocarcinoma predicts poor response and prognosis in patients with locally advanced rectal cancer: a pooled analysis of individual participant data from 3 prospective studies. Clin Colorectal Cancer, 2021, 20(4):e240 e248. https://doi.org/10.1016/j.clcc.2021.06.004 PMID: 34334298

[62] Gérard A, Buyse M, Nordlinger B, Loygue J, Pène F, Kempf P, Bosset JF, Gignoux M, Arnaud JP, Desaive C, Duez N. Preoperative radiotherapy as adjuvant treatment in rectal cancer. Final results of a randomized study of the European Organization for Research and Treatment of Cancer (EORTC). Ann Surg, 1988, 208(5):606-614. https://doi.org/10.1097/00 000658-198811000-00011 PMID: 3056288 PMCID: PMC 1493780

[63] Horn A, Morild I, Dahl O. Tumour shrinkage and down staging after preoperative radiation of rectal adenocarcinomas. Radiother Oncol, 1990, 18(1):19-28. https://doi.org/10.1016/0167-8140 (90)90019-s PMID: 2193318

[64] Berger C, de Muret A, Garaud P, Chapet S, Bourlier P, ReynaudBougnoux A, Dorval E, de Calan L, Huten N, le Folch O, Calais $\mathrm{G}$. Preoperative radiotherapy (RT) for rectal cancer: predictive factors of tumor downstaging and residual tumor cell density (RTCD): prognostic implications. Int J Radiat Oncol Biol Phys, 1997, 37(3):619-627. https://doi.org/10.1016/s03 60-3016(96)00577-9 PMID: 9112461

[65] Janjan NA, Khoo VS, Rich TA, Evetts PA, Goswitz MS, Allen PK, Skibber JM. Locally advanced rectal cancer: surgical complications after infusional chemotherapy and radiation therapy.
Radiology, 1998, 206(1):131-136. https://doi.org/10.1148/ radiology.206.1.9423662 PMID: 9423662

[66] Gérard JP, Conroy T, Bonnetain F, Bouché O, Chapet O, Closon-Dejardin MT, Untereiner M, Leduc B, Francois $E$, Maurel J, Seitz JF, Buecher B, Mackiewicz R, Ducreux M, Bedenne L. Preoperative radiotherapy with or without concurrent Fluorouracil and Leucovorin in T3-4 rectal cancers: results of FFCD 9203. J Clin Oncol, 2006, 24(28):4620-4625. https:// doi.org/10.1200/JCO.2006.06.7629 PMID: 17008704

[67] Allegra CJ, Yothers G, O'Connell MJ, Beart RW, Wozniak TF, Pitot HC, Shields AF, Landry JC, Ryan DP, Arora A, Evans LS, Bahary N, Soori G, Eakle JF, Robertson JM, Moore DF Jr, Mullane MR, Marchello BT, Ward PJ, Sharif S, Roh MS, Wolmark N. Neoadjuvant 5-FU or Capecitabine plus radiation with or without Oxaliplatin in rectal cancer patients: a phase III randomized clinical trial. J Natl Cancer Inst, 2015, 107(11): djv248. https://doi.org/10.1093/jnci/djv248 PMID: 26374429 PMCID: PMC4849360

[68] Garcia-Aguilar J, Chow OS, Smith DD, Marcet JE, Cataldo PA, Varma MG, Kumar AS, Oommen S, Coutsoftides T, Hunt SR, Stamos MJ, Ternent CA, Herzig DO, Fichera A, Polite BN, Dietz DW, Patil S, Avila K; Timing of Rectal Cancer Response to Chemoradiation Consortium. Effect of adding mFOLFOX6 after neoadjuvant chemoradiation in locally advanced rectal cancer: a multicentre, phase 2 trial. Lancet Oncol, 2015, 16(8): 957-966. https://doi.org/10.1016/S1470-2045(15)00004-2 PMID: 26187751 PMCID: PMC4670237

[69] Petrelli F, Trevisan F, Cabiddu M, Sgroi G, Bruschieri L, Rausa E, Ghidini M, Turati L. Total neoadjuvant therapy in rectal cancer: a systematic review and meta-analysis of treatment outcomes. Ann Surg, 2020, 271(3):440-448. https:// doi.org/10.1097/SLA.0000000000003471 PMID: 31318794

[70] Conroy T, Bosset JF, Etienne PL, Rio E, François É, MesgouezNebout N, Vendrely V, Artignan X, Bouché O, Gargot D, Boige V, Bonichon-Lamichhane N, Louvet C, Morand C, de la Fouchardière $C$, Lamfichekh N, Juzyna B, Jouffroy-Zeller $C$, Rullier E, Marchal F, Gourgou S, Castan F, Borg C; Unicancer Gastrointestinal Group and Partenariat de Recherche en Oncologie Digestive (PRODIGE) Group. Neoadjuvant chemotherapy with FOLFIRINOX and preoperative chemoradiotherapy for patients with locally advanced rectal cancer (UNICANCERPRODIGE 23): a multicentre, randomised, open-label, phase 3 trial. Lancet Oncol, 2021, 22(5):702-715. https://doi.org/10. 1016/S1470-2045(21)00079-6 PMID: 33862000

[71] Kalady MF, de Campos-Lobato LF, Stocchi L, Geisler DP, Dietz D, Lavery IC, Fazio VW. Predictive factors of pathologic complete response after neoadjuvant chemoradiation for rectal cancer. Ann Surg, 2009, 250(4):582-589. https://doi.org/10. 1097/SLA.0b013e3181b91e63 PMID: 19710605

[72] de Campos-Lobato LF, Geisler DP, da Luz Moreira A, Stocchi L, Dietz D, Kalady MF. Neoadjuvant therapy for rectal cancer: the impact of longer interval between chemoradiation and surgery. J Gastrointest Surg, 2011, 15(3):444-450. https:// doi.org/10.1007/s11605-010-1197-8 PMID: 21140237

[73] Sloothaak DAM, Geijsen DE, van Leersum NJ, Punt CJA, Buskens CJ, Bemelman WA, Tanis PJ; Dutch Surgical Colorectal Audit. Optimal time interval between neoadjuvant chemoradiotherapy and surgery for rectal cancer. Br J Surg, 2013, 100(7):933-999. https://doi.org/10.1002/bjs.9112 PMID: 23536485

[74] Neagu S, Lerescu L, Costea R, Tucureanu C, Caraş I, Gangură G, Pitica R, Sălăgeanu A. [Perioperative immunologic changes in colorectal cancer patients]. Chirurgia (Bucharest), 2012, 107(1):59-65. PMID: 22480118

[75] Dayde D, Gunther J, Hirayama Y, Weksberg DC, Boutin A, Parhy $\mathrm{G}$, Aguilar-Bonavides $\mathrm{C}$, Wang $\mathrm{H}$, Katayama $\mathrm{H}$, Abe $\mathrm{Y}$, Do KA, Hara K, Kinoshita T, Komori K, Shimizu Y, Tajika M, Niwa Y, Wang YA, DePinho R, Hanash S, Krishnan S, Taguchi A. Identification of blood-based biomarkers for the prediction of the response to neoadjuvant chemoradiation in rectal cancer. Cancers (Basel), 2021, 13(14):3642. https://doi.org/10.3390/ cancers13143642 PMID: 34298853 PMCID: PMC8306983

[76] Zorcolo L, Rosman AS, Restivo A, Pisano M, Nigri GR, Fancellu A, Melis M. Complete pathologic response after combined modality treatment for rectal cancer and long-term survival: a meta-analysis. Ann Surg Oncol, 2012, 19(9):28222832. https://doi.org/10.1245/s10434-011-2209-y PMID: 22434243

[77] Benson AB, Venook AP, Al-Hawary MM, Arain MA, Chen YJ, Ciombor KK, Cohen S, Cooper HS, Deming D, Garrido- 
Laguna I, Grem JL, Gunn A, Hoffe S, Hubbard J, Hunt S, Kirilcuk N, Krishnamurthi S, Messersmith WA, Meyerhardt J, Miller ED, Mulcahy MF, Nurkin S, Overman MJ, Parikh A Patel H, Pedersen K, Saltz L, Schneider C, Shibata D, Skibber JM, Sofocleous CT, Stoffel EM, Stotsky-Himelfarb E, Willett CG, Johnson-Chilla A, Gurski LA. NCCN Guidelines insights: rectal cancer, version 6.2020. J Natl Compr Canc Netw, 2020, 18(7):806-815. https://doi.org/10.6004/jnccn.2020. 0032 PMID: 32634771

[78] Wo JY, Anker CJ, Ashman JB, Bhadkamkar NA, Bradfield L, Chang DT, Dorth J, Garcia-Aguilar J, Goff D, Jacqmin D, Kelly P, Newman NB, Olsen J, Raldow AC, Ruiz-Garcia E, Stitzenberg KB, Thomas CR Jr, Wu QJ, Das P. Radiation therapy for rectal cancer: executive summary of an ASTRO Clinical Practice Guideline. Pract Radiat Oncol, 2021, 11(1):13-25. https://doi. org/10.1016/j.prro.2020.08.004 PMID: 33097436

[79] Stelzmueller I, Zitt M, Aigner F, Kafka-Ritsch R, Jäger R, De Vries A, Lukas P, Eisterer W, Bonatti H, Ofner D. Postoperative morbidity following chemoradiation for locally advanced low rectal cancer. J Gastrointest Surg, 2009, 13(4):657-667. https://doi.org/10.1007/s11605-008-0760-z PMID: 19082672

[80] Zarnescu Vasiliu EC, Zarnescu NO, Costea R, Neagu S. Review of risk factors for anastomotic leakage in colorectal surgery. Chirurgia (Bucharest), 2015, 110(4):319-326. PMID: 26305194

[81] Duldulao MP, Lee W, Le M, Wiatrek R, Nelson RA, Chen Z, Li W, Kim J, Garcia-Aguilar J. Surgical complications and pathologic complete response after neoadjuvant chemoradiation in locally advanced rectal cancer. Am Surg, 2011, 77(10): 1281-1285. PMID: 22127070

[82] Capirci C, Valentini V, Cionini L, De Paoli A, Rodel C, Glynne-Jones R, Coco C, Romano M, Mantello G, Palazzi S, Mattia FO, Friso ML, Genovesi D, Vidali C, Gambacorta MA, Buffoli A, Lupattelli M, Favretto MS, La Torre G. Prognostic value of pathologic complete response after neoadjuvant therapy in locally advanced rectal cancer: long-term analysis of 566 ypCR patients. Int J Radiat Oncol Biol Phys, 2008, 72(1):99107. https://doi.org/10.1016/j.jijobp.2007.12.019 PMID: 18407433

[83] Theodoropoulos G, Wise WE, Padmanabhan A, Kerner BA, Taylor CW, Aguilar PS, Khanduja KS. T-level downstaging and complete pathologic response after preoperative chemoradiation for advanced rectal cancer result in decreased recurrence and improved disease-free survival. Dis Colon Rectum, 2002, 45(7):895-903. https://doi.org/10.1007/s10350-004-6325-7 PMID: 12130878

[84] García-Aguilar J, Hernandez de Anda E, Sirivongs P, Lee SH, Madoff RD, Rothenberger DA. A pathologic complete response to preoperative chemoradiation is associated with lower local recurrence and improved survival in rectal cancer patients treated by mesorectal excision. Dis Colon Rectum, 2003, 46(3):298-304. https://doi.org/10.1007/s10350-004-6545-x PMID: 12626903

[85] Stipa F, Tierno SM, Russo G, Burza A. Trans-anal minimally invasive surgery (TAMIS) versus trans-anal endoscopic microsurgery (TEM): a comparative case-control matched-pairs analysis. Surg Endosc, 2021, Apr 12. https://doi.org/10.1007/s00464021-08494-y PMID: 33844090

[86] Atallah C, Taylor JP, Lo BD, Stem M, Brocke T, Efron JE, Safar B. Local excision for T1 rectal tumours: are we getting better? Colorectal Dis, 2020, 22(12):2038-2048. https://doi.org/ 10.1111/codi.15344 PMID: 32886836

[87] Junginger T, Goenner U, Hitzler M, Trinh TT, Heintz A, Blettner M, Wollschlaeger D. Long-term results of transanal endoscopic microsurgery after endoscopic polypectomy of malignant rectal adenoma. Tech Coloproctol, 2017, 21(3): 225-232. https://doi.org/10.1007/s10151-017-1595-y PMID: 28251355

[88] Serra-Aracil X, Pallisera-Lloveras A, Mora-Lopez L, SerraPla S, Puig-Diví V, Casalots À, Martínez-Bauer E, NavarroSoto $S$. Transanal endoscopic surgery is effective and safe after endoscopic polypectomy of potentially malignant rectal polyps with questionable margins. Colorectal Dis, 2018, 20(9): 789-796. https://doi.org/10.1111/codi.14108 PMID: 29577555

[89] Allaix ME, Arezzo A, Morino M. Transanal endoscopic microsurgery for rectal cancer: T1 and beyond? An evidence-based review. Surg Endosc, 2016, 30(11):4841-4852. https://doi.org/ 10.1007/s00464-016-4818-9 PMID: 26902614
[90] Bentrem DJ, Okabe S, Wong WD, Guillem JG, Weiser MR, Temple LK, Ben-Porat LS, Minsky BD, Cohen AM, Paty PB. T1 adenocarcinoma of the rectum: transanal excision or radical surgery? Ann Surg, 2005, 242(4):472-477; discussion 477479. https://doi.org/10.1097/01.sla.0000183355.94322.db PMID: 16192807 PMCID: PMC1402341

[91] Lee W, Lee D, Choi S, Chun H. Transanal endoscopic microsurgery and radical surgery for $\mathrm{T} 1$ and $\mathrm{T} 2$ rectal cancer. Surg Endosc, 2003, 17(8):1283-1287. https://doi.org/10.1007/ s00464-002-8814-x PMID: 12739119

[92] Ptok H, Marusch F, Meyer F, Schubert D, Koeckerling F, Gastinger I, Lippert H; Colon/Rectal Cancer (Primary Tumor) Study Group. Oncological outcome of local vs radical resection of low-risk pT1 rectal cancer. Arch Surg, 2007, 142:649-655; discussion 656. https://doi.org/10.1001/archsurg.142.7.649 PMID: 17638803

[93] De Graaf EJR, Doornebosch PG, Tollenaar RAEM, MeershoekKlein Kranenbarg E, de Boer AC, Bekkering FC, van de Velde $\mathrm{CJH}$. Transanal endoscopic microsurgery versus total mesorectal excision of T1 rectal adenocarcinomas with curative intention. Eur J Surg Oncol, 2009, 35(12):1280-1285. https:// doi.org/10.1016/j.ejso.2009.05.001 PMID: 19487099

[94] Nash GM, Weiser MR, Guillem JG, Temple LK, Shia J, Gonen M, Wong WD, Paty PB. Long-term survival after transanal excision of T1 rectal cancer. Dis Colon Rectum, 2009, 52(4):577-582. https://doi.org/10.1007/DCR.0b013e3181a0adbd PMID: 19404055

[95] Bosch SL, Teerenstra S, de Wilt JHW, Cunningham C, Nagtegaal ID. Predicting lymph node metastasis in pT1 colorectal cancer: a systematic review of risk factors providing rationale for therapy decisions. Endoscopy, 2013, 45(10):827834. https://doi.org/10.1055/s-0033-1344238 PMID: 23884793

[96] Morino M, Allaix ME, Caldart M, Scozzari G, Arezzo A. Risk factors for recurrence after transanal endoscopic microsurgery for rectal malignant neoplasm. Surg Endosc, 2011, 25(11): 3683-3690. https://doi.org/10.1007/s00464-011-1777-z PMID: 21647814

[97] Elmessiry MM, Van Koughnett JAM, Maya A, DaSilva G, Wexner SD, Bejarano P, Berho M. Local excision of T1 and T2 rectal cancer: proceed with caution. Colorectal Dis, 2014, 16(9): 703-709. https://doi.org/10.1111/codi.12657 PMID: 24787457

[98] Hompes R, Cunningham C. Extending the role of transanal endoscopic microsurgery (TEM) in rectal cancer. Colorectal Dis, 2011, 13(Suppl 7):32-36. https://doi.org/10.1111/j.14631318.2011.02778.x PMID: 22098515

[99] Greenberg JA, Shibata D, Herndon JE 2nd, Steele GD Jr, Mayer R, Bleday R. Local excision of distal rectal cancer: an update of cancer and leukemia group B 8984. Dis Colon Rectum, 2008, 51(8):1185-1191; discussion 1191-1194. https:// doi.org/10.1007/s10350-008-9231-6 PMID: 18536973

[100] Bach SP, Gilbert A, Brock K, Korsgen S, Geh I, Hill J, Gill T, Hainsworth P, Tutton MG, Khan J, Robinson J, Steward M, Cunningham C, Levy B, Beveridge A, Handley K, Kaur M, Marchevsky N, Magill L, Russell A, Quirke P, West NP, Sebag-Montefiore D; TREC collaborators. Radical surgery versus organ preservation via short-course radiotherapy followed by transanal endoscopic microsurgery for earlystage rectal cancer (TREC): a randomised, open-label feasibility study. Lancet Gastroenterol Hepatol, 2021, 6(2): 92-105. https://doi.org/10.1016/S2468-1253(20)30333-2 PMID: 33308452 PMCID: PMC7802515

[101] Calmels M, Collard MK, Cazelles A, Frontali A, Maggiori L, Panis Y. Local excision after neoadjuvant chemoradiotherapy versus total mesorectal excision: a case-matched study in 110 selected high-risk patients with rectal cancer. Colorectal Dis, 2020, 22(12):1999-2007. https://doi.org/10.1111/codi. 15323 PMID: 32813899

[102] Creavin B, Ryan E, Martin ST, Hanly A, O'Connell PR, Sheahan K, Winter DC. Organ preservation with local excision or active surveillance following chemoradiotherapy for rectal cancer. Br J Cancer, 2017, 116(2):169-174. https://doi.org/ 10.1038/bjc.2016.417 PMID: 27997526 PMCID: PMC5243997

[103] Nair RM, Siegel EM, Chen DT, Fulp WJ, Yeatman TJ, Malafa MP, Marcet J, Shibata D. Long-term results of transanal excision after neoadjuvant chemoradiation for T2 and T3 adenocarcinomas of the rectum. J Gastrointest Surg, 2008, 12(10):1797-1805; discussion 1805-1806. https:// doi.org/10.1007/s11605-008-0647-z PMID: 18709419 
[104] Debove C, Guedj N, Tribillon E, Maggiori L, Zappa M, Panis Y Local excision of low rectal cancer treated by chemoradiotherapy: is it safe for all patients with suspicion of complete tumor response? Int J Colorectal Dis, 2016, 31(4):853-860. https://doi.org/10.1007/s00384-016-2546-1 PMID: 26951185

[105] Stijns RCH, de Graaf EJR, Punt CJA, Nagtegaal ID, Nuyttens JJME, van Meerten E, Tanis PJ, de Hingh IHJT, van der Schelling GP, Acherman Y, Leijtens JWA, Bremers AJA, Beets GL, Hoff C, Verhoef C, Marijnen CAM, de Wilt JHW; CARTS Study Group. Long-term oncological and functional outcomes of chemoradiotherapy followed by organ-sparing transanal endoscopic microsurgery for distal rectal cancer: the CARTS Study. JAMA Surg, 2019, 154(1):47-54. https:// doi.org/10.1001/jamasurg.2018.3752 PMID: 30304338 PMCID: PMC6439861

[106] Rullier E, Rouanet P, Tuech JJ, Valverde A, Lelong B, Rivoire M, Faucheron JL, Jafari M, Portier G, Meunier B, Sileznieff I, Prudhomme M, Marchal F, Pocard M, Pezet D, Rullier A, Vendrely V, Denost Q, Asselineau J, Doussau A. Organ preservation for rectal cancer (GRECCAR 2): a prospective, randomised, open-label, multicentre, phase 3 trial. Lancet, 2017, 390(10093):469-479. https://doi.org/10. 1016/S0140-6736(17)31056-5 PMID: 28601342

[107] Chiloiro G, Meldolesi E, Giraffa M, Capocchiano ND, Barbaro B, Coco C, Corvari B, De Franco P, D'Ugo D, Alfieri S, Manfredi R, Valentini V, Gambacorta MA. Could the conservative approach be considered safe in the treatment of locally advanced rectal cancer in case of a clinical nearcomplete or complete response? A retrospective analysis. Clin Transl Radiat Oncol, 2021, 28:1-9. https://doi.org/10. 1016/j.ctro.2021.02.009 PMID: 33732909 PMCID: PMC 7937531

[108] Borstlap WAA, van Oostendorp SE, Klaver CEL, Hahnloser D, Cunningham C, Rullier E, Bemelman WA, Tuynman JB, Tanis PJ; Research Committee of the European Society of Coloproctology. Organ preservation in rectal cancer: a synopsis of current guidelines. Colorectal Dis, 2018, 20(3): 201-210. https://doi.org/10.1111/codi.13960 PMID: 29136328

[109] Caricato M, Borzomati D, Ausania F, Tonini G, Rabitti C, Valeri S, Trodella L, Ripetti V, Coppola R. Complementary use of local excision and transanal endoscopic microsurgery for rectal cancer after neoadjuvant chemoradiation. Surg Endosc, 2006, 20(8):1203-1207. https://doi.org/10.1007/s0 0464-005-0567-x PMID: 16703429

[110] Perez RO, Habr-Gama A, Lynn PB, São Julião GP, Bianchi R, Proscurshim I, Gama-Rodrigues J. Transanal endoscopic microsurgery for residual rectal cancer (ypT0-2) following neoadjuvant chemoradiation therapy: another word of caution. Dis Colon Rectum, 2013, 56(1):6-13. https://doi.org/10.1097/ DCR.0b013e318273f56f PMID: 23222274

[111] Shin YS, Park JH, Yoon SM, Kim JC, Yu CS, Lim SB, Park IJ, Kim TW, Hong YS, Kim KP, Choi EK, Ahn SD, Lee SW,
Kim JH. Total mesorectal excision versus local excision after preoperative chemoradiotherapy in rectal cancer with lymph node metastasis: a propensity score-matched analysis. Int $\mathrm{J}$ Radiat Oncol Biol Phys, 2018, 101(3):630-639. https://doi.org/ 10.1016/j.jirobp.2018.02.032 PMID: 29678529

[112] Habr-Gama A, Perez RO, Proscurshim I, Campos FG, Nadalin W, Kiss D, Gama-Rodrigues J. Patterns of failure and survival for nonoperative treatment of stage $\mathrm{c} 0$ distal rectal cancer following neoadjuvant chemoradiation therapy. J Gastrointest Surg, 2006, 10(10):1319-1328; discussion 1328-1329. https://doi.org/10.1016/j.gassur.2006.09.005 PMID: 17175450

[113] Han Z, Li M, Chen J, Ji D, Zhan T, Peng Y, Xue W, Li Y, Cai $Y$, Sun $Y$, Wu Q, Du C, Gu J. Surgery may not benefit patients with locally advanced rectal cancer who achieved clinical complete response following neoadjuvant chemoradiotherapy. Asian J Surg, 2022, 45(1):97-104. https://doi. org/10.1016/j.asjsur.2021.03.025 PMID: 33888366

[114] van der Valk MJM, Hilling DE, Bastiaannet E, MeershoekKlein Kranenbarg E, Beets GL, Figueiredo NL, Habr-Gama A, Perez RO, Renehan AG, van de Velde CJH; IWWD Consortium. Long-term outcomes of clinical complete responders after neoadjuvant treatment for rectal cancer in the International Watch \& Wait Database (IWWD): an international multicentre registry study. Lancet, 2018 , 391(10139):2537-2545. https://doi.org/10.1016/S0140-67 36(18)31078-X PMID: 29976470

[115] Pang K, Rao Q, Qin S, Jin L, Yao H, Zhang Z. Prognosis comparison between wait and watch and surgical strategy on rectal cancer patients after treatment with neoadjuvant chemoradiotherapy: a meta-analysis. Therap Adv Gastroenterol, 2019, 12:1756284819892477. https://doi.org/10. 1177/1756284819892477 PMID: 31832099 PMCID: PMC 6891008

[116] Haak HE, Maas M, Lambregts DMJ, Beets-Tan RGH, Beets GL; Dutch Watch-and-Wait Consortium. Is watch and wait a safe and effective way to treat rectal cancer in older patients? Eur J Surg Oncol, 2020, 46(3):358-362. https://doi.org/10.1016/j.ejso.2020.01.005 PMID: 31982206

[117] Fernandez LM, São Julião GP, Figueiredo NL, Beets GL, van der Valk MJM, Bahadoer RR, Hilling DE, MeershoekKlein Kranenbarg E, Roodvoets $A G H$, Renehan AG, van de Velde CJH, Habr-Gama A, Perez RO; International Watch \& Wait Database Consortium. Conditional recurrence-free survival of clinical complete responders managed by watch and wait after neoadjuvant chemoradiotherapy for rectal cancer in the International Watch \& Wait Database: a retrospective, international, multicentre registry study. Lancet Oncol, 2021, 22(1):43-50. https://doi.org/10.1016/S14702045(20)30557-X PMID: 33316218

\section{Corresponding author}

Ruxandra Doina Babiuc, Assistant Professor, MD, PhD, Department of Internal Medicine I - Gastroenterology, Emergency University Hospital Bucharest, Carol Davila University of Medicine and Pharmacy, 169 Independenţei Avenue, Sector 5, 050098 Bucharest, Romania; Phone +40721-837 070, e-mail: ruxandra.babiuc@umfcd.ro 